\title{
Waste Heat Recapture from Supermarket Refrigeration Systems
}

Final Report

Submitted to:

\author{
Refrigeration Project Team \\ Retail Energy Alliance
}

\author{
Prepared by: \\ Brian A. Fricke, Ph.D. \\ Oak Ridge National Laboratory \\ Oak Ridge, TN
}

4 October 2011 


\section{Contents}

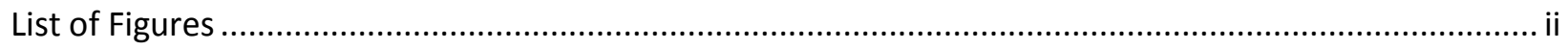

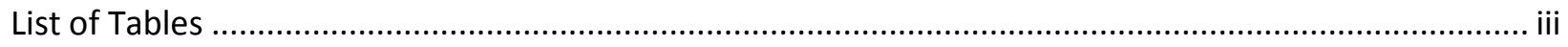

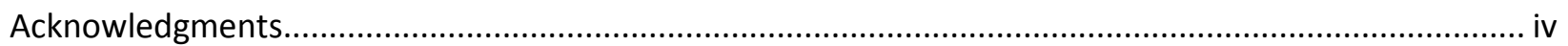

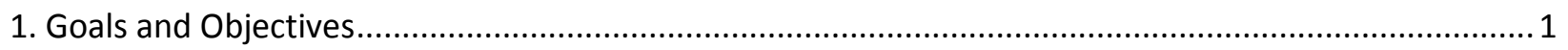

2. Motivation and Benefits of Waste Heat Utilization ...................................................................... 1

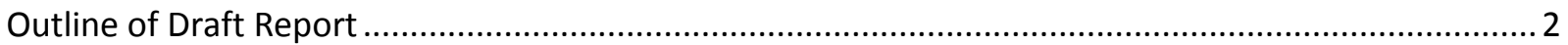

3. Amount of Waste Heat Available from Refrigeration Systems........................................................... 2

4. Methods and Applications of Heat Recovery ................................................................................ 11

Heat Recovery versus Floating Head Pressure …........................................................................... 12

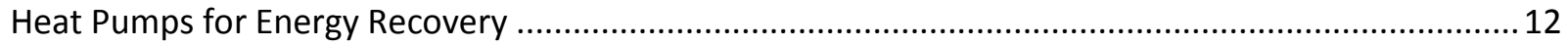

Regeneration in Desiccant Dehumidification Systems ................................................................. 17

Trigeneration or Combined Cooling, Heat and Power (CCHP) ........................................................ 17

Analytical Study by Maidment and Tozer (2002) ........................................................................ 19

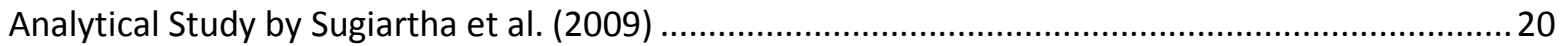

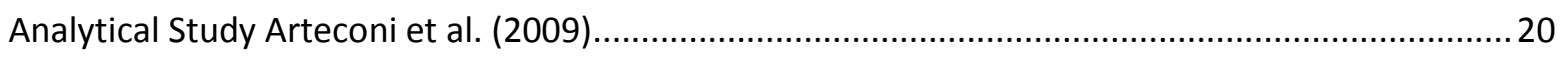

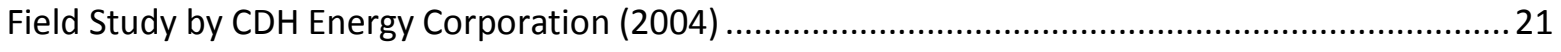

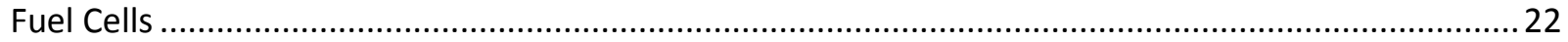

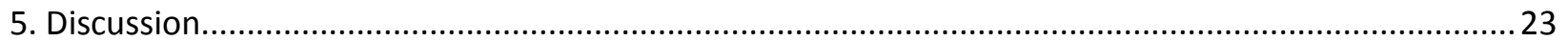

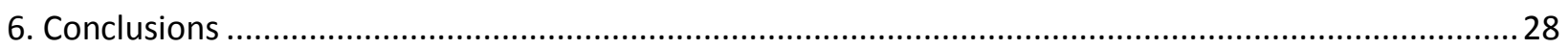

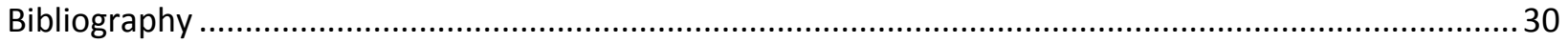




\section{List of Figures}

Figure 1. Schematic diagram of a hypothetical refrigeration cycle.

Figure 2. Pressure-enthalpy $(p-h)$ diagram for a hypothetical low-temperature R-407A refrigeration

cycle.

Figure 3. Pressure-enthalpy $(p-h)$ diagram for a hypothetical medium-temperature R-407A refrigeration

cycle. 6

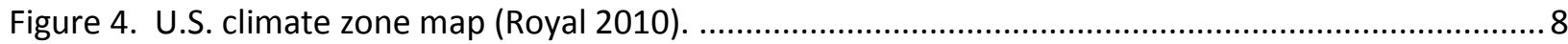

Figure 5. Basic supermarket refrigeration system with heat recovery (Minea 2010)............................11

Figure 6. Low temperature zone with secondary loops and heat pumps (Minea 2007).........................14

Figure 7. Medium temperature zone with secondary loops and a heat recovery heat exchanger (Minea

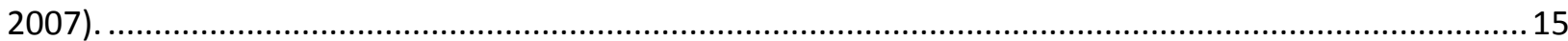

Figure 8. Dual path water-source heat pump system utilized in Wal-Mart field study (Khattar 2004).... 16 


\section{List of Tables}

Table 1. Thermodynamic States for Hypothetical Low-Temperature R-407A Refrigeration System.......... 4

Table 2. Thermodynamic States for Hypothetical Medium Temperature R-407A Refrigeration System. .. 6

Table 3. Climate Zones and Representative Cities (Royal 2010)........................................................... 8

Table 4. Heating Hours at Various Bin Temperatures for a Big Box Retail Store (Royal 2010)...................9

Table 5. Full Condensing Heat Recovery Energy Available from a Medium Temperature Refrigeration

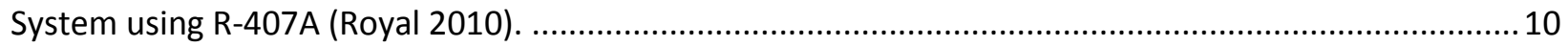

Table 6. Specification of Representative Supermarket Refrigeration System (Walker 2001) ..................24

Table 7. Cooling Capacity and Heating Load of Representative Supermarket in Various Cities (Walker

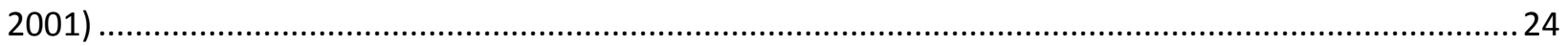

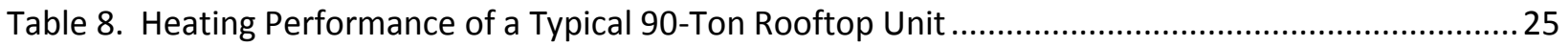

Table 9. Summary of Advanced Heat Recovery Technologies.............................................................. 27 


\section{Acknowledgments}

The authors would like to thank the U.S. Department of Energy for its support of this project. The authors would also like to thank the support of the members of the Refrigeration Project Team of the Retail Energy Alliance.

This document was prepared by the Oak Ridge National Laboratory, Building Equipment Research Group, Energy \& Transportation Science Division. 


\section{Waste Heat Recapture from Supermarket Refrigeration Systems}

\section{Goals and Objectives}

The objective of this project was to determine the potential energy savings associated with improved utilization of waste heat from supermarket refrigeration systems. Existing and advanced strategies for waste heat recovery in supermarkets were analyzed, including options from advanced sources such as combined heat and power (CHP), micro-turbines and fuel cells.

\section{Motivation and Benefits of Waste Heat Utilization}

Retail food stores and supermarkets operate their refrigeration systems continuously to maintain proper food storage conditions within their refrigerated display cases and storage areas. The continual operation of this equipment accounts for approximately $50 \%$ of the total electrical energy consumption of a typical supermarket (Westphalen, et al. 1996). Furthermore, a significant amount of waste heat is rejected by the condensers of supermarket refrigeration systems. Unfortunately, this waste heat is of low quality, meaning that its temperature is low. Thus, practical uses of waste heat from supermarket refrigeration systems are typically limited to space heating and water heating.

In an effort to more effectively utilize waste heat, the temperature of the waste heat may be increased, to a limited degree, by raising the condensing pressure of the refrigeration system. However, studies have shown that raising the condensing pressure to achieve higher quality waste heat uses more energy than it saves. Reasons cited include poorly designed heat recovery systems and a lack of sophistication in the control systems for the refrigeration and HVAC systems (Arias and Lundqvist 2006).

Recently, several researchers have attempted to more effectively utilize the waste heat from supermarket refrigeration systems using various other techniques. Use of waste heat to drive heat pumps for space heating and/or cooling has been proposed. In addition, waste heat may be used to preheat the regeneration air flow used in solid desiccant adsorption dehumidification systems or to preheat the liquid desiccant in absorption dehumidification systems.

More advanced supermarket energy systems include the use of trigeneration or combined cooling, heat and power (CCHP) to efficiently produce power, cooling and heating. Fuel cell technology is also being used in a limited number of supermarkets in order to efficiently generate electrical power and to effectively utilize the resulting waste heat. 


\section{Outline of Draft Report}

This report presents a review of waste heat recovery from supermarket refrigeration systems and describes the current application of heat recovery in supermarket applications. In addition, this report presents case studies and information regarding the utilization of advanced sources of waste heat such as combined heat and power (CHP) and fuel cells.

The following outline summarizes the remaining content of this report.

- Section 3, Amount of Waste Heat Available from Refrigeration Systems

The types of heat recovery, i.e., desuperheating heat recovery and full condensing heat recovery, are discussed. In addition, examples are given to illustrate the amount of heat which can be obtained from medium- and low-temperature refrigeration systems of typical supermarkets and big box retail stores.

- Section 4, Methods and Applications of Heat Recovery

A summary of supermarket refrigeration system heat recovery methods and applications is given. The heat recovery methods and applications discussed in Section 3 include heat pumps, desiccant regeneration, trigeneration and fuel cells.

- Section 5, Discussion

The suitability of the various heat recovery methods and applications discussed in Section 3 with regard to supermarkets is discussed.

- Section 6, Conclusions

Conclusions and recommendations regarding waste heat recovery from supermarket refrigeration systems are given.

\section{Amount of Waste Heat Available from Refrigeration Systems}

The waste heat recovered from a commercial refrigeration system typically consists of either only the heat which is required to desuperheat the compressor discharge gas, or both the heat required to desuperheat the discharge gas as well as the heat required to condense the refrigerant from a saturated vapor to a saturated liquid. The waste heat from the former is known as desuperheating waste heat while that from the latter is known as full condensing waste heat. Less waste heat is recovered through only desuperheating as compared to full condensing, however the quality of the heat recovered by only desuperheating is higher, i.e., the temperature of the waste heat from desuperheating is higher than that obtained from full condensing.

The quality and quantity of waste heat available for recovery depends upon the operation of the refrigeration system. The temperature of the compressor discharge gas determines the quality of the waste heat. This temperature in turn is dependent upon the temperature of the return gas at the 
compressor suction header. The compressor discharge temperature is also affected by the saturated condensing temperature. As the condensing temperature decreases, the discharge temperature decreases. The optimum conditions for operating the refrigeration system, i.e., operating at the highest suction pressure and lowest condensing pressure, leads to the minimum amount of available waste heat. However, it is much more effective to operate the refrigeration system at its most efficient conditions with a minimum amount of waste heat than it is to operate the refrigeration system less efficiently in order to produce more waste heat.

The end use of the waste heat dictates whether only desuperheating or full condensing heat recovery should be used. For example, a typical hot water system for a supermarket or big box retail store may require a water circulation temperature as high as $140^{\circ} \mathrm{F}$. At this temperature, only desuperheating waste heat recovery can be effectively employed, and additional electric heaters may be required to achieve the desired water temperature (Royal 2010).

Compared to water heating, preheating of ventilation air requires waste heat of lower quality. When preheating ventilation air with an air-cooled fluid cooler for heat reclaim, an entering water temperature of $60^{\circ} \mathrm{F}$ and a leaving water temperature of $45^{\circ} \mathrm{F}$ are typical (Royal 2010). Thus, the lower quality waste heat from full condensing may be used to preheat ventilation air. Typically, full condensing heat recovery applications are designed for use with water-cooled refrigeration systems.

To determine the amount of heat which can be recovered from a commercial refrigeration system, consider a low-temperature refrigeration cycle using R-407A as the refrigerant. A schematic of this cycle is shown in Figure 1 while Figure 2 shows the various states of this cycle on a pressure-enthalpy $(p-h)$ diagram.

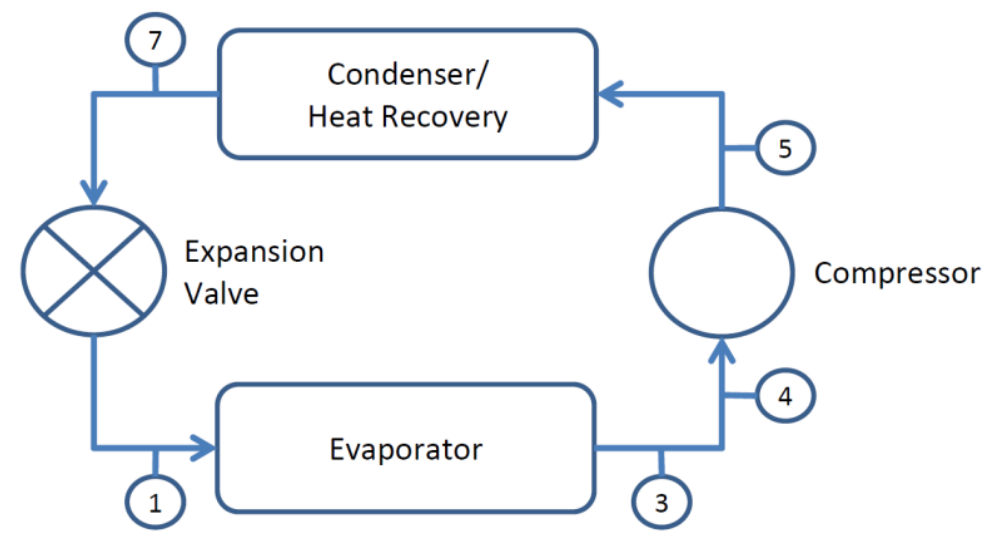

Figure 1. Schematic diagram of a hypothetical refrigeration cycle. 


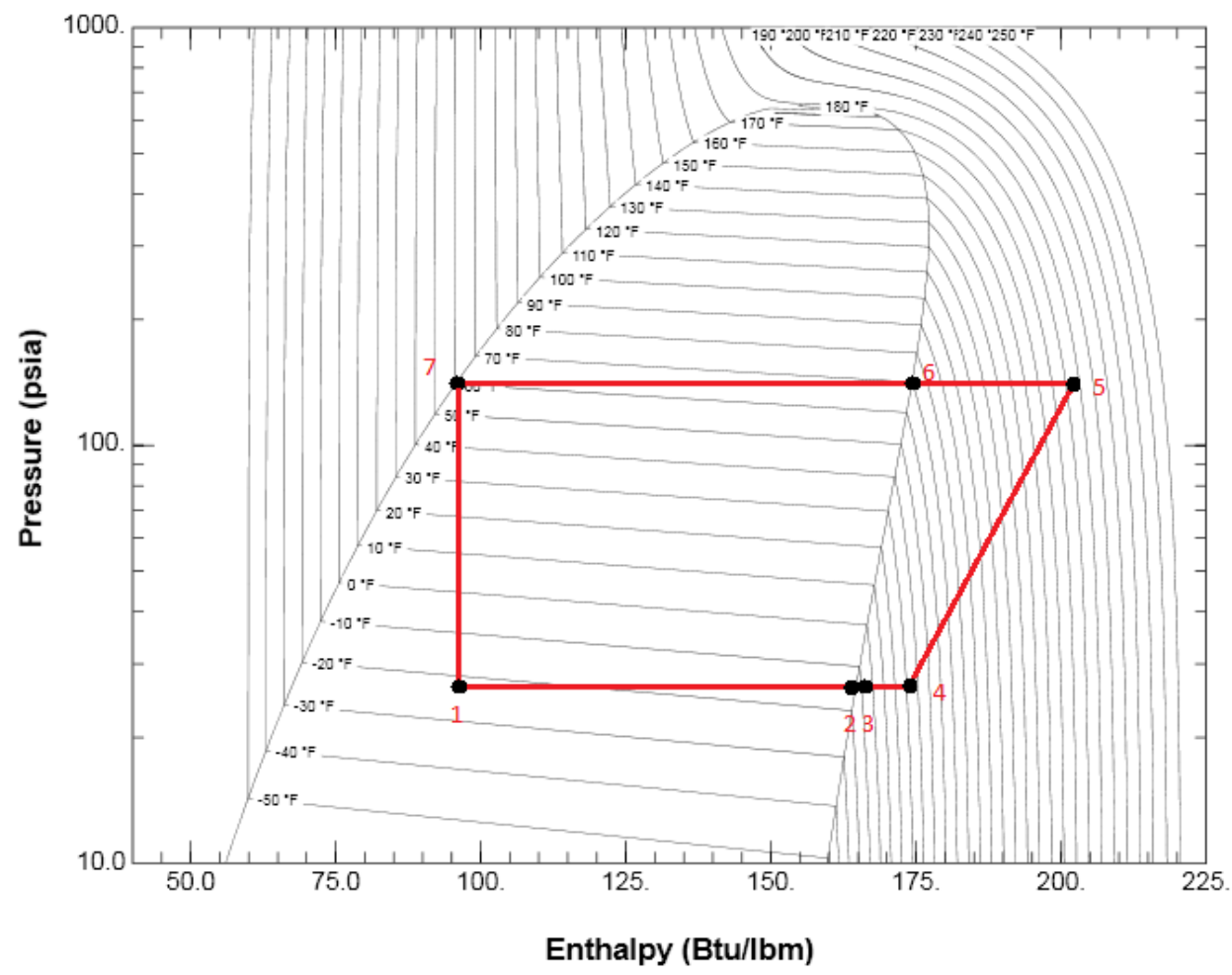

Figure 2. Pressure-enthalpy $(p-h)$ diagram for a hypothetical low-temperature R-407A refrigeration cycle.

For the refrigeration cycle shown in Figure 1 and Figure 2, the average saturated condensing temperature is assumed to be $65^{\circ} \mathrm{F}\left(18.3^{\circ} \mathrm{C}\right)$ and the average saturated evaporating temperature is assumed to be $-20^{\circ} \mathrm{F}\left(-28.9^{\circ} \mathrm{C}\right)$. In addition, a superheat of $6^{\circ} \mathrm{F}\left(3.3^{\circ} \mathrm{C}\right)$ is assumed the exit of the evaporator (location 3 ) and the return gas temperature at the compressor suction header is $30^{\circ} \mathrm{F}$ $\left(-1.1^{\circ} \mathrm{C}\right)$ (location 4$)$. The isentropic efficiency of the compressor is assumed to be $65 \%$. Finally, no subcooling is considered in the condenser and no pressure drops are considered in the refrigerant piping. The thermodynamic states, including temperature, pressure, enthalpy, entropy and quality, around this hypothetical refrigeration cycle are shown in Table 1.

Table 1. Thermodynamic States for Hypothetical Low-Temperature R-407A Refrigeration System.

\begin{tabular}{cccccc}
\hline \hline State Point & $\begin{array}{c}\text { Temperature } \\
\left({ }^{\circ} \mathrm{F}\right)\end{array}$ & $\begin{array}{c}\text { Pressure } \\
(\mathrm{psia})\end{array}$ & $\begin{array}{c}\text { Enthalpy } \\
\left(\mathrm{Btu} / \mathrm{lb}_{\mathrm{m}}\right)\end{array}$ & $\begin{array}{c}\text { Entropy } \\
\left(\mathrm{Btu} / \mathrm{lb}_{\mathrm{m}} \cdot \mathrm{R}\right)\end{array}$ & Quality \\
\hline 1 & -23.81 & 26.0 & 95.768 & 0.2643 & 0.29 \\
2 & -15.36 & 26.0 & 164.56 & 0.4206 & 1.00 \\
3 & -9.00 & 26.0 & 165.80 & 0.4234 & -- \\
4 & 30.00 & 26.0 & 173.39 & 0.4396 & - \\
5 & 187.35 & 141 & 202.53 & 0.4559 & - \\
6 & 69.17 & 141 & 174.27 & 0.4076 & 1.00 \\
7 & 60.51 & 141 & 95.768 & 0.2580 & 0.00 \\
\hline \hline
\end{tabular}


For the conditions shown in Table 1, the total heat available from full condensing heat recovery, $q_{f c}$, is:

$$
q_{f c}=h_{5}-h_{7}=202.53 \mathrm{Btu} / \mathrm{lbm}-95.768 \mathrm{Btu} / \mathrm{lbm}=106.76 \mathrm{Btu} / \mathrm{lbm}
$$

where $h_{5}$ is the enthalpy of the discharge gas from the compressor and $h_{7}$ is the enthalpy of saturated liquid refrigerant leaving the condenser. To get an indication of the magnitude of the waste heat available from a low-temperature refrigeration system in an average-sized supermarket with a plan area of $40,000 \mathrm{ft}^{2}\left(3,720 \mathrm{~m}^{2}\right)$, assume that the refrigerant flow rate for a low-temperature refrigeration system is approximately $3,800 \mathrm{lb} / \mathrm{mr}(1,720 \mathrm{~kg} / \mathrm{hr})$. Then, the amount of heat recovered from full condensing heat recovery would be on the order of 406,000 Btu/hr (119 kW).

Similarly, the heat available from desuperheating, $q_{d s h}$, is only:

$$
q_{d s h}=h_{5}-h_{6}=202.53 \mathrm{Btu} / \mathrm{lbm}-174.27 \mathrm{Btu} / \mathrm{lbm}=28.26 \mathrm{Btu} / \mathrm{lbm}
$$

where $h_{6}$ is the enthalpy of saturated vapor refrigerant at the condensing pressure. Again, if the refrigerant flow rate for the low-temperature refrigeration system is assumed to be $3,800 \mathrm{lb} / \mathrm{hr}$ $(1,720 \mathrm{~kg} / \mathrm{hr})$, then the amount of heat recovered from desuperheating would be on the order of $107,000 \mathrm{Btu} / \mathrm{hr}(31.4 \mathrm{~kW})$. Thus, desuperheating, $q_{d s h}$, accounts for only $26 \%$ of the full condensing heat recovery, $q_{f c}$, for the low-temperature refrigeration system.

Also note that the average temperature of the refrigerant during desuperheating is approximately $127^{\circ} \mathrm{F}$ $\left(52.8^{\circ} \mathrm{C}\right.$ ) while the average temperature of the refrigerant during full condensing (which includes both desuperheating and condensing) is approximately $81^{\circ} \mathrm{F}\left(27.2^{\circ} \mathrm{C}\right)$. Thus, it can be seen that the quality (or temperature) of the desuperheating waste heat is considerably higher than that of the full condensing waste heat.

A similar analysis can be performed for a medium-temperature refrigeration cycle. Consider the same basic R-407A refrigeration cycle shown in Figure 1, this time with the various states of the mediumtemperature cycle shown in the $p$ - $h$ diagram in Figure 3.

For the medium-temperature refrigeration cycle depicted in Figure 1 and Figure 3, the average saturated condensing temperature is assumed to be $65^{\circ} \mathrm{F}\left(18.3^{\circ} \mathrm{C}\right)$ and the average saturated evaporating temperature is assumed to be $20^{\circ} \mathrm{F}\left(-6.7^{\circ} \mathrm{C}\right)$. In addition, a superheat of $8^{\circ} \mathrm{F}\left(4.4^{\circ} \mathrm{C}\right)$ is assumed at the exit of the evaporator (location 3 ) and the return gas temperature at the compressor suction header is $50^{\circ} \mathrm{F}\left(10^{\circ} \mathrm{C}\right)$ (location 4). The isentropic efficiency of the compressor is assumed to be $65 \%$. Finally, no subcooling is considered in the condenser and no pressure drops are considered in the refrigerant piping. The thermodynamic states, including temperature, pressure, enthalpy, entropy and quality, around this hypothetical refrigeration cycle are shown in Table 2.

For the conditions shown in Table 2 , the total heat available from full condensing heat recovery, $q_{f c}$, is:

$$
q_{f c}=h_{5}-h_{7}=188.50 \mathrm{Btu} / \mathrm{lbm}-95.768 \mathrm{Btu} / \mathrm{lbm}=92.73 \mathrm{Btu} / \mathrm{lbm}
$$


where $h_{5}$ is the enthalpy of the discharge gas from the compressor and $h_{7}$ is the enthalpy of saturated liquid refrigerant leaving the condenser. To get an indication of the magnitude of the waste heat available from a medium-temperature refrigeration system in an average-sized supermarket with a plan area of $40,000 \mathrm{ft}^{2}\left(3,720 \mathrm{~m}^{2}\right)$, assume that the refrigerant flow rate for a medium-temperature refrigeration system is approximately $6,400 \mathrm{lb} / \mathrm{hr}(2,900 \mathrm{~kg} / \mathrm{hr})$. Then the amount of heat recovered from full condensing heat recovery would be on the order of 593,000 Btu/hr (174 kW).

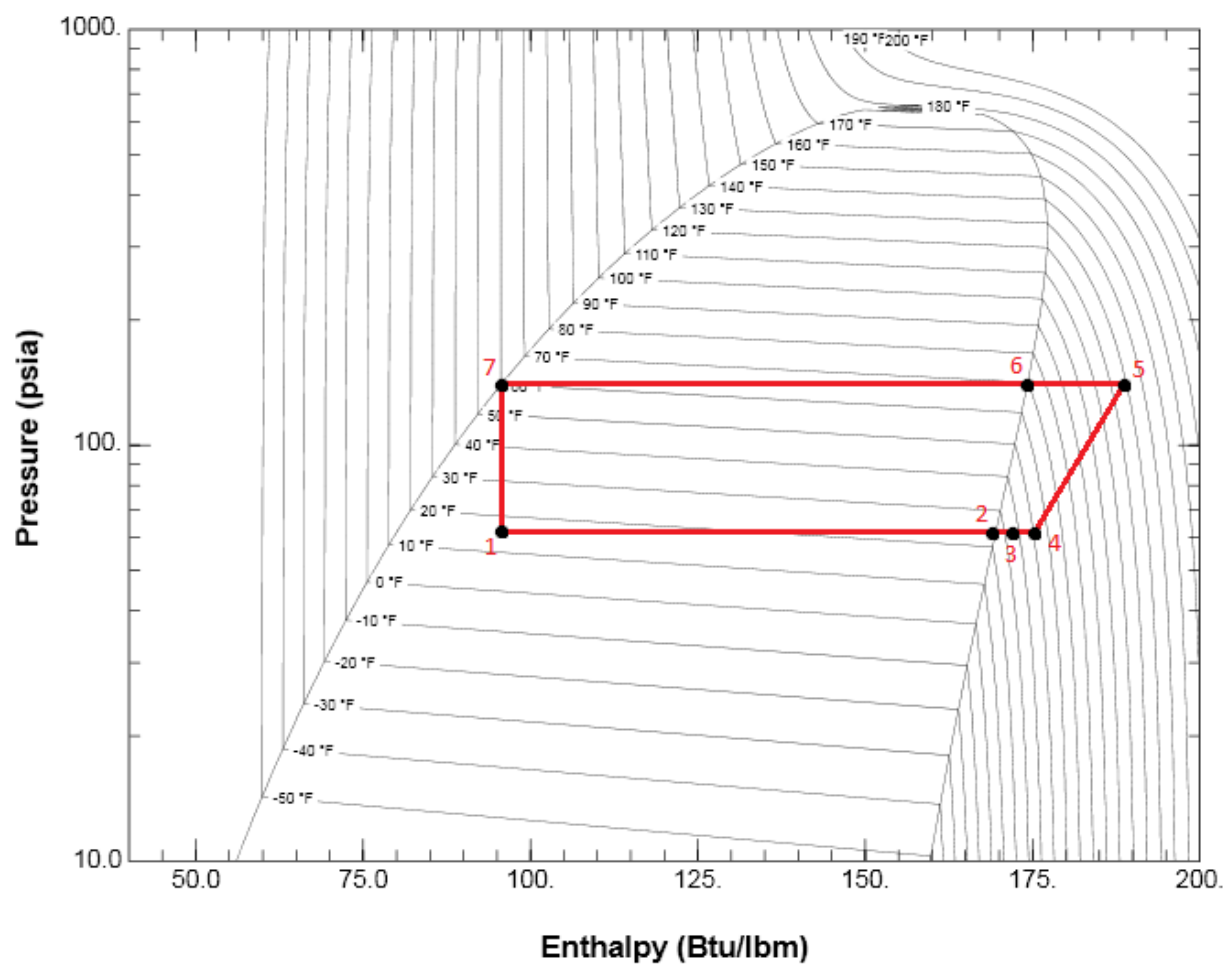

Figure 3. Pressure-enthalpy $(p-h)$ diagram for a hypothetical medium-temperature R-407A refrigeration cycle.

Table 2. Thermodynamic States for Hypothetical Medium Temperature R-407A Refrigeration System.

\begin{tabular}{cccccc}
\hline State Point & $\begin{array}{c}\text { Temperature } \\
\left({ }^{\circ} \mathrm{F}\right)\end{array}$ & $\begin{array}{c}\text { Pressure } \\
(\mathrm{psia})\end{array}$ & $\begin{array}{c}\text { Enthalpy } \\
\left(\mathrm{Btu} / \mathrm{lb}_{\mathrm{m}}\right)\end{array}$ & $\begin{array}{c}\text { Entropy } \\
\left(\mathrm{Btu} / \mathrm{lb}_{\mathrm{m}} \cdot \mathrm{R}\right)\end{array}$ & Quality \\
\hline 1 & 15.32 & 62.0 & 95.768 & 0.2599 & 0.17 \\
2 & 24.16 & 62.0 & 169.52 & 0.4138 & 1.00 \\
3 & 32.00 & 62.0 & 171.24 & 0.4173 & -- \\
4 & 50.00 & 62.0 & 175.12 & 0.4250 & - \\
5 & 127.83 & 141 & 188.50 & 0.4332 & - \\
6 & 69.17 & 141 & 174.27 & 0.4076 & 1.00 \\
7 & 60.51 & 141 & 95.768 & 0.2580 & 0.00 \\
\hline \hline
\end{tabular}


Similarly, the heat available from desuperheating, $q_{d s h}$, is only:

$$
q_{d s h}=h_{5}-h_{6}=188.50 \mathrm{Btu} / \mathrm{lbm}-174.27 \mathrm{Btu} / \mathrm{lbm}=14.23 \mathrm{Btu} / \mathrm{lbm}
$$

where $h_{6}$ is the enthalpy of saturated vapor refrigerant at the condensing pressure. Again, if the refrigerant flow rate for the medium-temperature refrigeration system is assumed to be $6,400 \mathrm{lb} / \mathrm{hr}$ $(2,900 \mathrm{~kg} / \mathrm{hr})$, then the amount of heat recovered from desuperheating would be on the order of $91,000 \mathrm{Btu} / \mathrm{hr}(26.7 \mathrm{~kW})$. Thus, desuperheating, $q_{d s h}$, accounts for only $15 \%$ of the full condensing heat recovery, $q_{f c}$, for the medium-temperature refrigeration system.

Also note that the average temperature of the refrigerant during desuperheating is approximately $98^{\circ} \mathrm{F}$ $\left(36.7^{\circ} \mathrm{C}\right)$ while the average temperature of the refrigerant during full condensing (which includes both desuperheating and condensing) is approximately $70^{\circ} \mathrm{F}\left(21.1^{\circ} \mathrm{C}\right)$. Thus, it can be seen that the quality (or temperature) of the desuperheating waste heat is considerably higher than that of the full condensing waste heat.

To carry this example farther, consider that the medium-temperature refrigeration system shown in Figure 1 and Figure 3 is utilized in a typical big box retail store, where full condensing heat recovery from the refrigeration system will be used to preheat ventilation air. The amount of waste heat available for this purpose depends upon the operating conditions of the refrigeration system and the climate zone in which the store is located. In this example, the refrigeration system condensing temperature is set at $65^{\circ} \mathrm{F}\left(18.3^{\circ} \mathrm{C}\right)$ and the refrigerant is $\mathrm{R}-407 \mathrm{~A}$. Suppose that the medium-temperature refrigeration system has a total heat rejection of $770,192 \mathrm{Btu} / \mathrm{hr}(226 \mathrm{~kW})$, which is on the order of that for a big box retail store (Royal 2010). The prototypical big box retail building has an average heating load of $2.1 \times 10^{6} \mathrm{Btu} / \mathrm{hr}(610 \mathrm{~kW})$ and no space heating is required when the outdoor air temperature is greater than $47.5^{\circ} \mathrm{F}\left(8.6^{\circ} \mathrm{C}\right)$. Furthermore, the analysis will consider the 13 US climates zones shown in Figure 4. Table 3 lists a representative city for each climate zone along with the average annual dry-bulb temperature for each representative city (Royal 2010).

For the typical big box retail store, Table 4 shows the number of hours of space heating which is required in each temperature bin for the 13 climate zones. Table 5 shows the amount of waste heat energy available in each temperature bin for the 13 climate zones. This waste heat energy is determined from the total heat rejection from the refrigeration system (770,192 Btu/hr or $226 \mathrm{~kW})$ and the number of hours in each particular temperature bin. The total waste heat available for recovery in each climate zone is summed at the bottom of each column (Royal 2010).

As can be seen from Table 5, for increasingly warmer climate zones, the total amount of waste heat from the refrigeration system which can be used for preheating purposes decreases. For example, in Casper, WY (located in the coolest climate zone), the total amount of waste heat which can be used for air preheating is 4,135,927 MBtu (4.36 TJ), while in Miami, FL (located in the warmest climate zone), the total amount of waste heat which can be used for air preheating is $77,790 \mathrm{MBtu}(82.1 \mathrm{GJ})$. The use of waste heat for ventilation air preheating is therefore more cost effective in colder climates than in warmer climates. In warmer climates, where the requirement for preheating of ventilation air is lower, it might be more effective to use the waste heat from the refrigeration system for water heating 
purposes. Thus, the application of waste heat from refrigeration systems must consider both the amount of heat available from the refrigeration system and the location of the store.

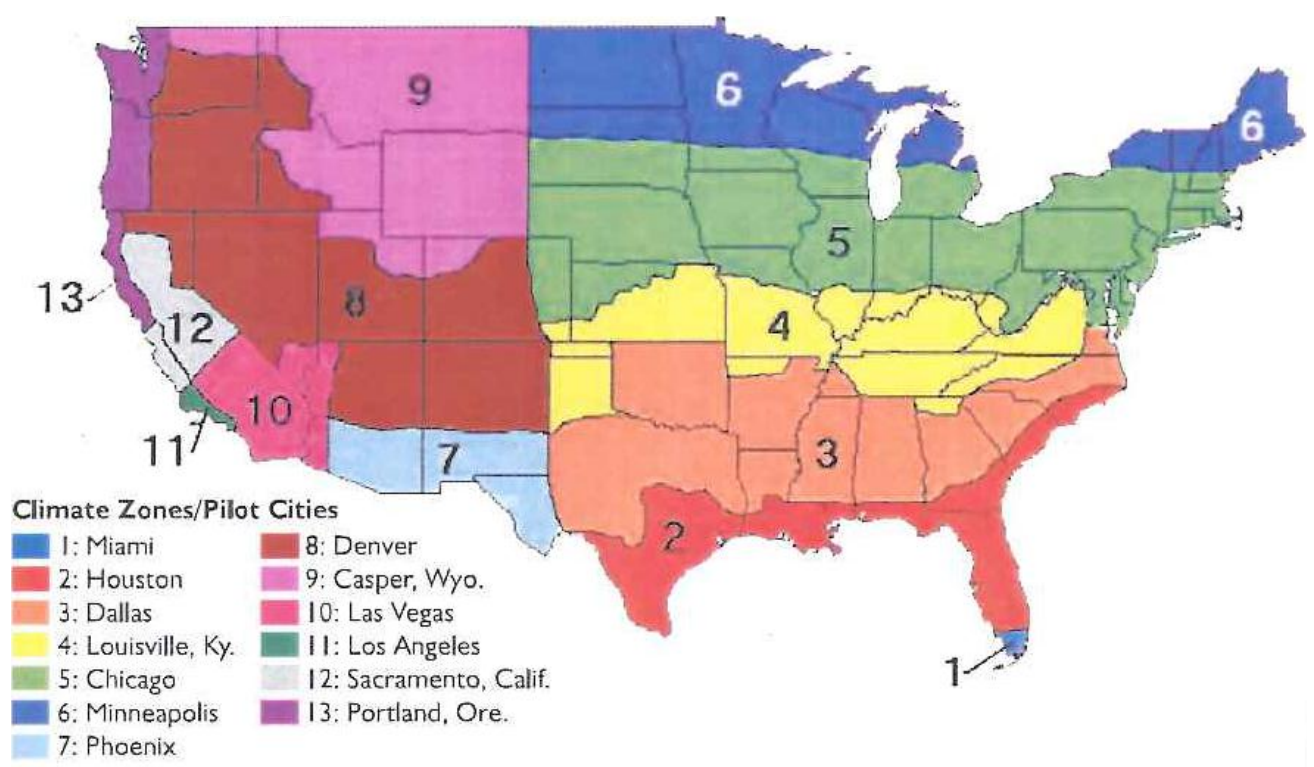

Figure 4. U.S. climate zone map (Royal 2010).

Table 3. Climate Zones and Representative Cities (Royal 2010).

\begin{tabular}{ccc}
\hline \hline Climate Zone & Representative City & $\begin{array}{c}\text { Average Annual Dry-Bulb } \\
\text { Temperature }\left({ }^{\circ} \mathrm{F}\right)\end{array}$ \\
\hline 1 & Miami, FL & 76.9 \\
2 & Houston, TX & 70.2 \\
3 & Dallas, TX & 66.2 \\
4 & Louisville, KY & 57.1 \\
5 & Chicago, IL & 50.0 \\
6 & Minneapolis, MN & 46.3 \\
7 & Phoenix, AZ & 74.9 \\
8 & Denver, CO & 50.7 \\
9 & Casper, WY & 46.2 \\
10 & Las Vegas, NV & 68.4 \\
11 & Los Angeles, CA & 63.2 \\
12 & Sacramento, CA & 61.4 \\
13 & Portland, OR & 54.6 \\
\hline \hline
\end{tabular}


Table 4. Heating Hours at Various Bin Temperatures for a Big Box Retail Store (Royal 2010).

\begin{tabular}{|c|c|c|c|c|c|c|c|c|c|c|c|c|c|c|}
\hline \multirow{3}{*}{$\begin{array}{c}\text { Outside Air } \\
\text { Temperature } \\
\left({ }^{\circ} \mathrm{F}\right)\end{array}$} & \multirow{3}{*}{$\begin{array}{c}\text { Condensing } \\
\text { Temperature } \\
\left({ }^{\circ} \mathrm{F}\right)\end{array}$} & \multicolumn{13}{|c|}{ Climate Zone } \\
\hline & & 1 & 2 & 3 & 4 & 5 & 6 & 7 & 8 & 9 & 10 & 11 & 12 & 13 \\
\hline & & \multicolumn{13}{|c|}{ Bin Hours } \\
\hline 47.5 & 65 & 73 & 436 & 637 & 582 & 595 & 544 & 467 & 748 & 754 & 860 & 245 & 1048 & 1436 \\
\hline 42.5 & 65 & 19 & 335 & 535 & 632 & 590 & 418 & 456 & 775 & 777 & 404 & 38 & 745 & 1264 \\
\hline 37.5 & 65 & 9 & 217 & 383 & 494 & 734 & 560 & 181 & 834 & 864 & 340 & & 470 & 647 \\
\hline 32.5 & 65 & & 126 & 199 & 705 & 714 & 603 & 58 & 611 & 691 & 159 & & 68 & 253 \\
\hline 27.5 & 65 & & 59 & 138 & 455 & 772 & 552 & 8 & 648 & 814 & 24 & & & 61 \\
\hline 22.5 & 65 & & 19 & 27 & 268 & 417 & 380 & & 320 & 498 & & & & 74 \\
\hline 17.5 & 65 & & 6 & 16 & 224 & 305 & 468 & & 201 & 329 & & & & \\
\hline 12.5 & 65 & & & & 93 & 124 & 307 & & 110 & 183 & & & & \\
\hline 7.5 & 65 & & & & 63 & 105 & 204 & & 97 & 175 & & & & \\
\hline 2.5 & 65 & & & & 14 & 56 & 169 & & 86 & 107 & & & & \\
\hline-2.5 & 65 & & & & & 40 & 93 & & 37 & 63 & & & & \\
\hline-7.5 & 65 & & & & & 28 & 110 & & 15 & 38 & & & & \\
\hline-12.5 & 65 & & & & & & 71 & & & 45 & & & & \\
\hline-17.5 & 65 & & & & & & 26 & & & 20 & & & & \\
\hline \multirow[t]{2}{*}{-22.5} & 65 & & & & & & & & & 12 & & & & \\
\hline & Total Hours & 101 & 1198 & 1935 & 3530 & 4480 & 4505 & 1170 & 4482 & 5370 & 1787 & 283 & 2331 & 3735 \\
\hline
\end{tabular}


Table 5. Full Condensing Heat Recovery Energy Available from a Medium Temperature Refrigeration System using R-407A (Royal 2010).

\begin{tabular}{|c|c|c|c|c|c|c|c|c|c|c|c|c|c|c|}
\hline \multirow{3}{*}{$\begin{array}{c}\text { Outside } \\
\text { Air Temp. } \\
\quad\left({ }^{\circ} \mathrm{F}\right)\end{array}$} & \multirow{3}{*}{$\begin{array}{c}\text { Total Heat } \\
\text { Rejection } \\
\text { (Btu/hr) }\end{array}$} & \multicolumn{13}{|c|}{ Climate Zone } \\
\hline & & 1 & 2 & 3 & 4 & 5 & 6 & 7 & 8 & 9 & 10 & 11 & 12 & 13 \\
\hline & & \multicolumn{13}{|c|}{ Refrigeration Heat Energy Available (MBtu)* } \\
\hline 47.5 & 770192 & 56224 & 335804 & 490612 & 448251 & 458264 & 418984 & 359679 & 576103 & 580724 & 662365 & 188697 & 807161 & 1105995 \\
\hline 42.5 & 770192 & 14634 & 258014 & 412052 & 486761 & 454413 & 321940 & 351207 & 596898 & 598439 & 311157 & 29267 & 576793 & 973522 \\
\hline 37.5 & 770192 & 6932 & 167132 & 294983 & 380475 & 565321 & 431307 & 139405 & 642340 & 665445 & 261865 & 0 & 361990 & 498314 \\
\hline 32.5 & 770192 & 0 & 97044 & 153268 & 542985 & 549917 & 464425 & 44671 & 470587 & 532202 & 122460 & 0 & 52373 & 194858 \\
\hline 27.5 & 770192 & 0 & 45441 & 106286 & 350437 & 594588 & 425146 & 6162 & 499084 & 626936 & 18485 & 0 & 0 & 46982 \\
\hline 22.5 & 770192 & 0 & 14634 & 20795 & 206411 & 321170 & 292673 & 0 & 246461 & 383555 & 0 & 0 & 0 & 56994 \\
\hline 17.5 & 770192 & 0 & 4621 & 12323 & 172523 & 234908 & 360450 & 0 & 154808 & 253393 & 0 & 0 & 0 & 0 \\
\hline 12.5 & 770192 & 0 & 0 & 0 & 71628 & 95504 & 236449 & 0 & 84721 & 140945 & 0 & 0 & 0 & 0 \\
\hline 7.5 & 770192 & 0 & 0 & 0 & 48522 & 80870 & 157119 & 0 & 74709 & 134784 & 0 & 0 & 0 & 0 \\
\hline 2.5 & 770192 & 0 & 0 & 0 & 10783 & 43131 & 130162 & 0 & 66236 & 82410 & 0 & 0 & 0 & 0 \\
\hline-2.5 & 770192 & 0 & 0 & 0 & 0 & 30808 & 71628 & 0 & 28497 & 48522 & 0 & 0 & 0 & 0 \\
\hline-7.5 & 770192 & 0 & 0 & 0 & 0 & 21565 & 84721 & 0 & 11553 & 29267 & 0 & 0 & 0 & 0 \\
\hline-12.5 & 770192 & 0 & 0 & 0 & 0 & 0 & 54684 & 0 & 0 & 34659 & 0 & 0 & 0 & 0 \\
\hline-17.5 & 770192 & 0 & 0 & 0 & 0 & 0 & 20025 & 0 & 0 & 15404 & 0 & 0 & 0 & 0 \\
\hline \multirow[t]{2}{*}{-22.5} & 770192 & 0 & 0 & 0 & 0 & 0 & 0 & 0 & 0 & 9242 & 0 & 0 & 0 & 0 \\
\hline & $\begin{array}{l}\text { Total } \\
\text { MBtu }\end{array}$ & 77790 & 922690 & 1490319 & 2718776 & 3450459 & 3469713 & 901124 & 3451997 & 4135927 & 1376332 & 217964 & 1798317 & 2876665 \\
\hline
\end{tabular}

* One MBtu = 1,000 Btu 


\section{Methods and Applications of Heat Recovery}

Currently in the U.S., the typical supermarket refrigeration system is the multiplex, direct expansion system type, in which direct expansion evaporator coils are located within the refrigerated display cases and walk-in coolers and freezers, and the compressors and condensers are located in a machine room at the back of the store or on the roof of the store. Supply and return piping delivers refrigerant to and from the evaporators in the display cases and walk-in coolers/freezers.

As shown in Figure 5, in a basic direct expansion (DX) refrigeration system, a heat recovery heat exchanger (HRC) can be used to transfer heat from the compressor discharge gas to either the retail space or to process water. The heat to be extracted from the high pressure, high temperature discharge gas consists of both superheat (sensible) and condensing (latent) heat. Any excess heat that is not recovered is rejected to the outdoor ambient via an air-cooled condenser.

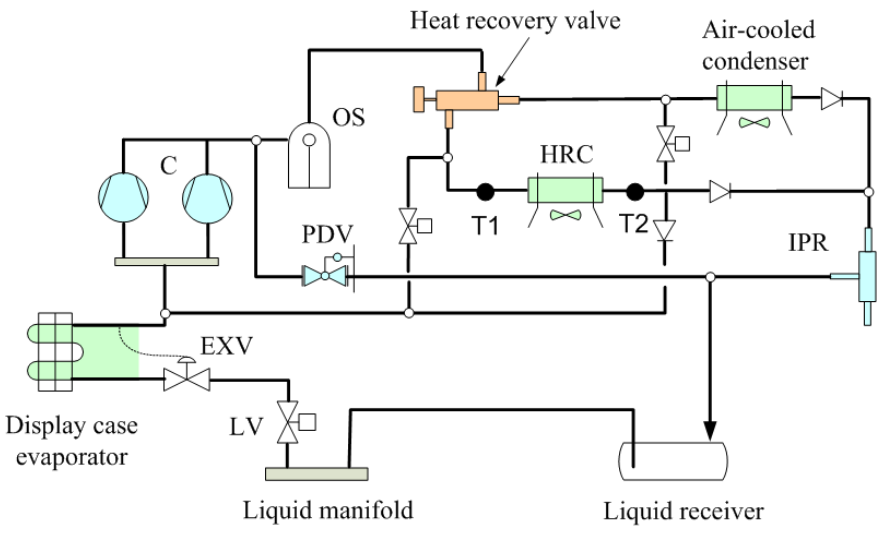

(a)

Figure 5. Basic supermarket refrigeration system with heat recovery (Minea 2010).

Heat reclaimed by desuperheating the compressor discharge can be used for space heating or water heating. However, the heat recovered by partial or full condensing of the refrigerant can only be used for space heating, provided that the refrigeration system head pressure is high enough to reclaim usable heat (Walker, Tsaros and Deming 1990).

If the refrigeration system is operated in cold climates using floating condenser pressure control, the condensing temperature and pressure will be low, resulting in low quality, low temperature waste heat that is unavailable for practical use. The head pressure may be maintained at a level higher than required during cold weather in order to produce higher quality waste heat. However, the electrical energy consumption of the refrigeration system at the higher condensing pressure may be greater than the amount of useful heat recovered (Minea 2010).

Minea (2010) reports the refrigerant discharge temperatures entering and exiting a heat recovery coil for a period of one year, for a particular supermarket with a basic DX refrigeration system located in Canada. The temperature of the refrigerant entering the heat recovery coil varied between $140^{\circ} \mathrm{F}\left(60^{\circ} \mathrm{C}\right)$ and $176^{\circ} \mathrm{F}\left(80^{\circ} \mathrm{C}\right)$ over the course of the year. Minea noted that the amount of heat recovered was not sufficient to provide full space heating for the supermarket. 
Thus, various researchers have attempted to improve the utilization of waste heat from supermarket refrigeration systems.

\section{Heat Recovery versus Floating Head Pressure}

The operation of vapor compression refrigeration systems always requires the rejection of waste heat to the environment. In colder climates, such as northern Europe or Canada, it would seem logical then to use this waste heat to provide heating for the supermarket space or for process water. However, in an attempt to increase the efficiency of the refrigeration system, the head pressure can be allowed to float, or follow, the outdoor ambient temperature. Thus, as the outdoor temperature decreases, the temperature of the refrigeration system waste heat decreases. Therefore, the amount of space heating or water heating that can be achieved at lower ambient temperatures decreases.

As a compromise between utilizing either a heat recovery strategy or a floating head pressure control strategy in supermarket refrigeration systems, Arias and Lundqvist (2006) propose to use both. In order to do so, Arias and Lundqvist suggest that two refrigeration systems be used in place of one refrigeration system. Where one refrigeration system is optimized to operate with floating head pressure or heat recovery, two smaller systems can be used instead, with one system optimized to provide heat recovery while the other is optimized to operate with floating head pressure.

Using a supermarket energy simulation tool, Arias and Lundqvist modeled an existing Swedish supermarket using the following three strategies:

- Heat recovery only

- Floating head pressure only

- Both heat recovery and floating head pressure

Arias and Lundqvist found that the energy rejected by the condenser should be sufficient to meet the space heating requirements of the supermarket. However, practical experience at the existing supermarket indicates that this is not the case, due to cyclic operation of the refrigeration system and the poor integration of heat recovery between the refrigeration system and the HVAC system. Furthermore, the simulation results indicated that the combined heat recovery and floating head pressure strategy was more economical than either only the heat recovery strategy or only the floating head pressure strategy. It was found that the total energy cost savings was approximately $7 \%$ to $8 \%$ by using both heat recovery and floating head pressure versus either heat recovery or floating head pressure alone.

\section{Heat Pumps for Energy Recovery}

In an effort to increase the quality of refrigeration system waste heat, heat pumps which are driven by the waste heat have been used for supermarket space heating. These heat pumps can be integrated into the supermarket HVAC system either directly, where the heat pump evaporators serve as refrigeration system condensers, or indirectly, where water-source heat pumps receive refrigeration system waste heat via water-cooled condensers. An advantage of using heat pumps to recover waste 
heat is that the refrigeration system head pressure does not need to be maintained at a high level in order to reclaim usable heat (Baxter 2003).

Heat pump heat recovery has been investigated in a supermarket in Canada (Baxter 2003). A supermarket with a traditional multiplex direct expansion refrigeration system consisting of two racks, one for medium temperature and the other for low temperature, was fitted with several rooftop heat pumps. Discharge gas from the refrigeration system passes through plate heat exchangers which serve as the evaporators of the heat pumps. These heat pumps supply heating to the supermarket. It was reported that this system reduced overall energy consumption of the supermarket by about $6 \%$ while costing approximately $8 \%$ more than a conventional refrigeration and HVAC system (Baxter 2003).

Water-source heat pumps in conjunction with water loop heat rejection have been evaluated for use in supermarkets, and it was estimated that a combination of water-cooled distributed refrigeration systems with water-source heat pumps could save $10 \%$ to $20 \%$ in overall refrigeration plus HVAC operating costs. The installed cost of this type of system was estimated to be $30 \%$ more than that of a conventional rooftop HVAC system with a simple payback of between 4.2 to 7.8 years (Baxter 2003).

Minea (2006) (2007) utilized a supermarket refrigeration system which consisted of secondary loops on both the refrigerating and condensing sides of the system, in conjunction with heat pumps and heat exchangers for heat recovery. The refrigeration system is divided into two zones: a low-temperature zone and a medium-temperature zone.

As shown in Figure 6, the low-temperature zone of the supermarket refrigeration system consists of three separate closed loops: 1) a low-temperature R-507 vapor compression refrigeration loop with a design suction temperature of $\left.-20^{\circ} \mathrm{F}\left(-28.9^{\circ} \mathrm{C}\right), 2\right)$ a "freezing" loop supplying low temperature brine to the refrigerated display cases and storage rooms, and 3) a heat rejection loop supplying a high temperature solution to the heat rejection device (fluid cooler) and heat recovery devices (heat pumps). 


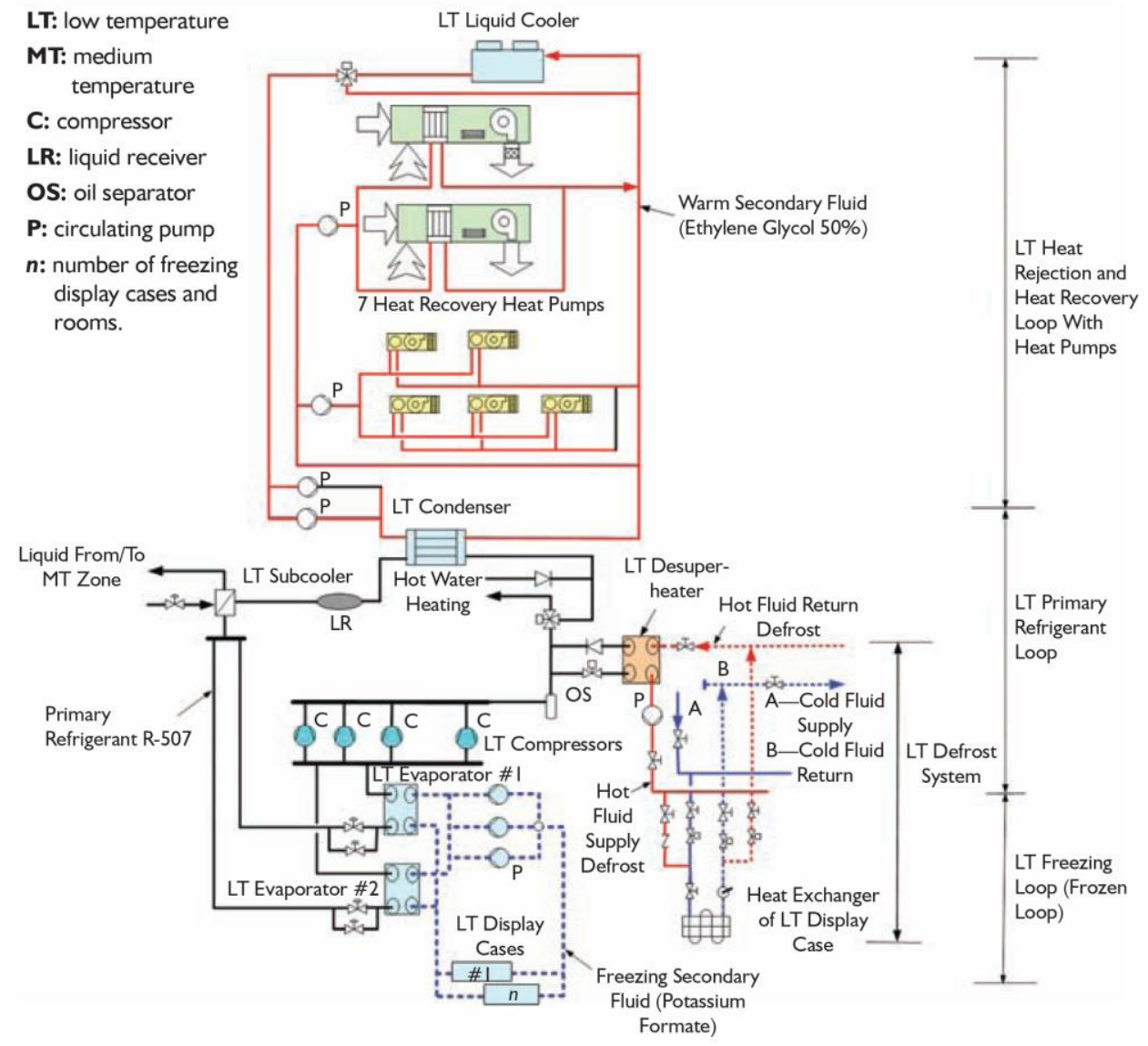

Figure 6. Low temperature zone with secondary loops and heat pumps (Minea 2007).

In the low-temperature zone, a potassium formate salt brine is cooled via the evaporator of the R-507 refrigeration system and pumped to the heat exchangers within the display cases and storage rooms. In order to defrost the display case and storage room heat exchangers, the potassium formate brine is heated during defrost cycles via a desuperheating heat exchanger installed in the discharge line from the compressors. The condenser of the low temperature R-507 refrigeration system transfers heat from the refrigeration system to an ethylene glycol solution which is pumped to the fluid cooler and seven brineto-air heat pumps. Six of the brine-to air heat pumps are used to heat the receiving and storage areas as well as the store entrance/vestibule area while the seventh brine-to-air heat pump provides heating and cooling to the community room. Any excess heat is then rejected by the fluid cooler.

Similarly, as shown in Figure 7, the medium-temperature zone consists of three separate closed loops: 1) a medium-temperature $R-507$ vapor compression refrigeration loop with a design suction temperature of $\left.20^{\circ} \mathrm{F}\left(-6.7^{\circ} \mathrm{C}\right), 2\right)$ a "cooling" loop supplying a medium-temperature liquid solution to the display cases and storage rooms, and 3 ) a heat rejection loop supplying a high temperature liquid solution to the heat rejection devices (fluid coolers) and the heat recovery heat exchanger in the central HVAC unit. 


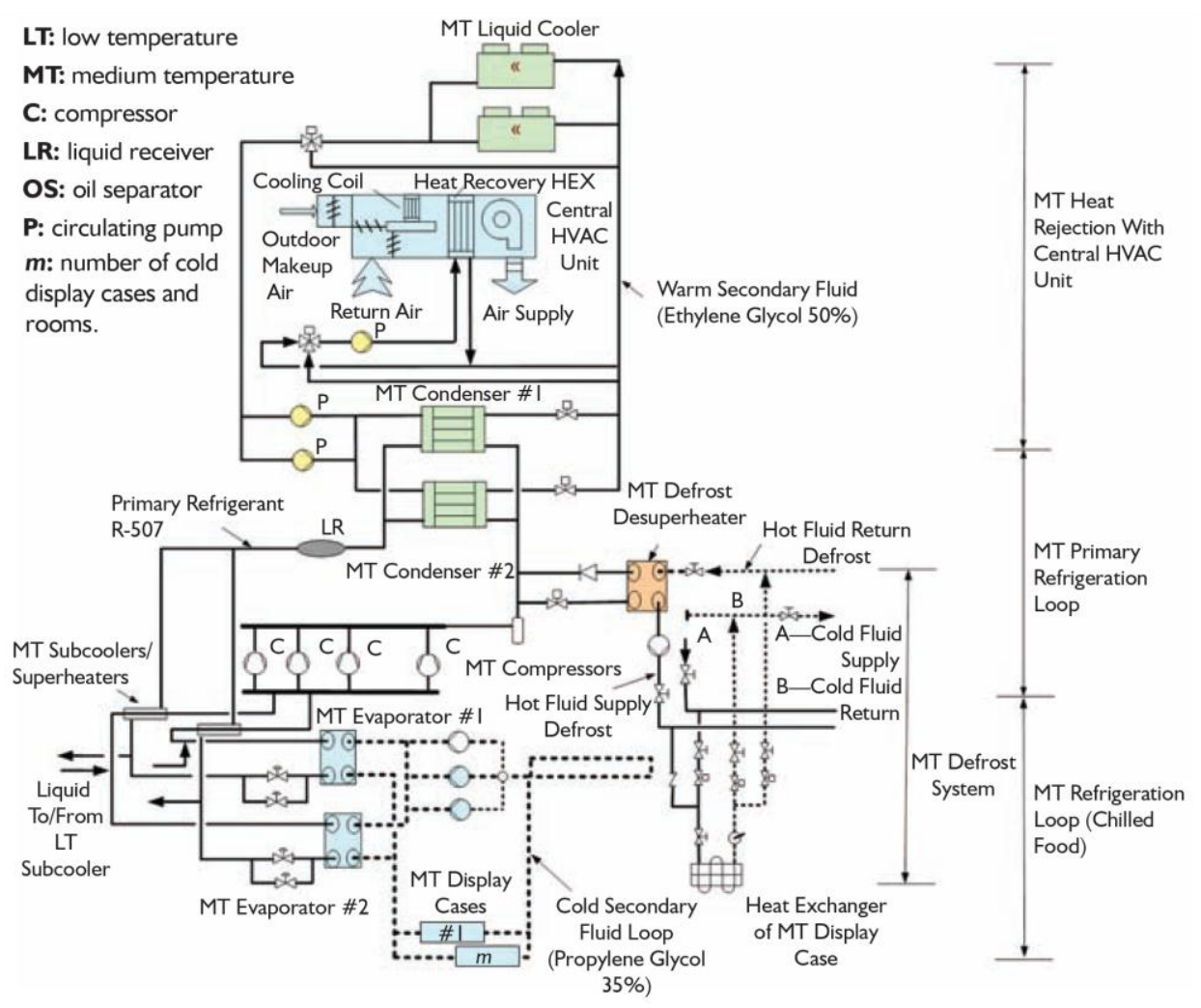

Figure 7. Medium temperature zone with secondary loops and a heat recovery heat exchanger (Minea 2007).

In the medium-temperature zone, a propylene glycol/water solution is cooled via the evaporator of the R-507 refrigeration system and pumped to the heat exchangers within the display cases and storage rooms. In order to defrost the display case and storage room heat exchangers, the propylene glycol solution is heated during defrost cycles via a desuperheating heat exchanger installed in the discharge line from the compressors. The condenser of the medium-temperature R-507 refrigeration system transfers heat from the refrigeration system to an ethylene glycol solution which is pumped to the fluid coolers and the heat recovery heat exchanger.

The refrigeration system proposed by Minea $(2006,2007)$ was installed in a new supermarket near Montreal. The overall size of the supermarket was $117,578 \mathrm{ft}^{2}\left(11,000 \mathrm{~m}^{2}\right)$ with a total sales area of $74,842 \mathrm{ft}^{2}\left(7,000 \mathrm{~m}^{2}\right)$. The low- and medium-temperature $\mathrm{R}-507$ refrigeration cycles are confined to a $1,410 \mathrm{ft}^{2}\left(130 \mathrm{~m}^{2}\right)$ machine room. The integrated secondary loop refrigeration and HVAC system was monitored during a 12-month period to determine energy performance in a cold Canadian climate.

It was found that the temperature of the warm secondary fluid in the heat rejection loop of the lowtemperature zone never dropped below $77^{\circ} \mathrm{F}\left(25^{\circ} \mathrm{C}\right)$ during the coldest weather and exceeded $104^{\circ} \mathrm{F}$ $\left(40^{\circ} \mathrm{C}\right)$ during the warmest weather. The brine-to-air heat pumps on the low-temperature heat rejection loop achieved coefficients of performance (COPs) as high as 4.6 while the outdoor temperatures dropped to $-13^{\circ} \mathrm{F}\left(-25^{\circ} \mathrm{C}\right)$. 
The temperature of the warm secondary fluid in the heat rejection loop of the medium-temperature zone frequently exceeded $86^{\circ} \mathrm{F}\left(30^{\circ} \mathrm{C}\right)$ during the winter months, thereby providing useful waste heat for preheating outdoor make-up air via the brine-to-air heat exchanger in the central HVAC unit. It was noted that the back-up electrical heater in the central HVAC unit did not operate during the winter suggesting that there was sufficient waste heat for preheating the outdoor make-up air.

The specific annual energy consumption of the supermarket was found to be $841 \mathrm{kWh} / \mathrm{m}^{2}$ per year. Minea (2007) noted that this energy consumption is less than that of conventional direct expansion multiplex systems in Canada, which generally exceed $1000 \mathrm{kWh} / \mathrm{m}^{2}$ per year. The main components of the low- and medium-temperature refrigeration systems, including compressors, secondary fluid pumps and liquid cooler fans, consumed approximately $30 \%$ of the supermarket's total annual energy.

Furthermore, the use of cooling/freezing and heat rejection fluid loops significantly reduced the refrigerant charge of the system as compared to conventional direct expansion multiplex systems. Minea (2007) estimates that, compared to a baseline multiplex refrigeration system, the refrigerant charge of the secondary loop system was reduced by $61 \%$.

Khattar (2004) investigated the performance of a dual-path, water-source heat pump HVAC system in a supercenter located in Moore, OK. A schematic of the dual path HVAC system used in the field demonstration is shown in Figure 8. This system was used to provide variable ventilation rate through the ventilation air path, conditioned ventilation air below a set point of $45^{\circ} \mathrm{F}\left(7^{\circ} \mathrm{C}\right)$ at all airflow rates, and space heating through recovery of refrigeration waste heat from a circulating water loop. This system used a water-cooled DX coiling coil in the ventilation air path and a water-source heat pump in the recirculation air path. A central circulating water loop was used in which the waste heat from the refrigeration racks was transferred to the rooftop HVAC units. Cooling towers were used to reject the excess heat in the water loop which was not used for space heating.

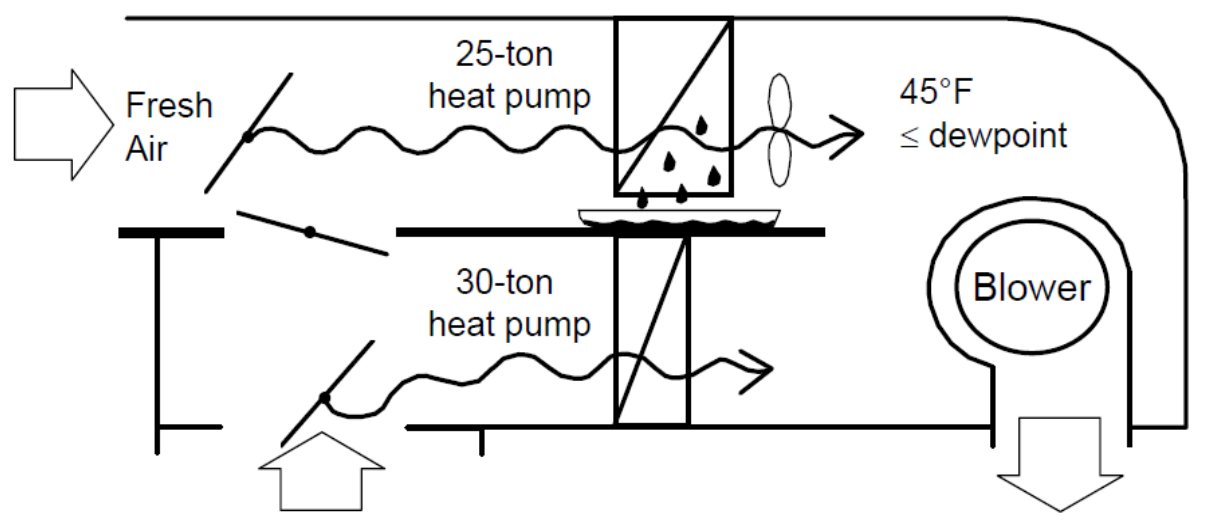

Recirculation Air

Dry, Cool Supply Air

Figure 8. Dual path water-source heat pump system utilized in Wal-Mart field study (Khattar 2004). 
Khattar (2004) found that this dual path HVAC system was capable of maintaining the indoor dew point between $45^{\circ} \mathrm{F}$ to $48^{\circ} \mathrm{F}\left(7^{\circ} \mathrm{C}\right.$ to $\left.9^{\circ} \mathrm{C}\right)$ regardless of outdoor dew point temperature (unless the outdoor dew point fell below $45^{\circ} \mathrm{F}\left(7^{\circ} \mathrm{C}\right)$, in which case, the indoor dew point also dropped). This corresponds to a relative humidity range of approximately $40 \%$ to $45 \%$ at $70^{\circ} \mathrm{F}\left(21^{\circ} \mathrm{C}\right)$. Furthermore, no additional heat was required to maintain space conditions in the winter other than the heat which was recovered from the water loop. Thus, it was demonstrated that the refrigeration waste heat could be practically and efficiently used, without the need for additional heat sources.

\section{Regeneration in Desiccant Dehumidification Systems}

Brandemuehl and Khattar (1997) provide data from field monitoring of a desiccant-based HVAC system installed in a $38,427 \mathrm{ft}^{2}\left(3,570 \mathrm{~m}^{2}\right)$ New Jersey supermarket. The original HVAC system at this supermarket was a conventional rooftop DX cooling system which provided cooling and dehumidification. The system provided 75 tons $(265 \mathrm{~kW})$ of cooling and dehumidification capacity with a supply airflow of $28,000 \mathrm{cfm}(13,200 \mathrm{~L} / \mathrm{s})$. The system was then retrofitted with an all-electric desiccant dehumidifying system. The modified system consisted of the original rooftop unit, with reduced airflow (18,000 cfm or 8,494 L/s) and reduced capacity ( 45 tons or $158 \mathrm{~kW})$. The desiccant system had a supply air flow rating of $7,000 \mathrm{cfm}(3,300 \mathrm{~L} / \mathrm{s})$, a regeneration air flow rating of 4,400 $\mathrm{cfm}$ $(2,080 \mathrm{~L} / \mathrm{s})$ and a total fan power of $8.8 \mathrm{~kW}$. Waste heat from the refrigeration system was used to regenerate the desiccant material. The desiccant material that was used in the system was newly developed, and could be effectively regenerated at temperatures as low as $130^{\circ} \mathrm{F}\left(54^{\circ} \mathrm{C}\right)$.

Two zones were created with the air distribution system: the desiccant system served the freezer aisles while a conventional DX system served the remainder of the store. Thus, the desiccant system could focus dehumidification in the freezer aisles where the greatest benefit from dehumidification could be realized.

Brandemuehl and Khattar (1997) found that the new desiccant-based system was able to maintain a substantial humidity gradient across the supermarket, where the freezer aisles had a lower humidity than the main grocery aisles. The desiccant system heats and dehumidifies the supply air. It was found that the additional heat added to the store did not appear to increase the cooling energy use of the HVAC system. The heat generally provided beneficial warming to the freezer aisles, improving occupant comfort. The heat added to the supermarket by the desiccant system was less than the need for reheat with a conventional HVAC system.

\section{Trigeneration or Combined Cooling, Heat and Power (CCHP)}

Combined heat and power (CHP) systems consist of equipment to produce and utilize both heat and power. Typically, gas engines or gas turbines drive an electric generator to produce electric power. The waste heat from the engine exhaust, engine cooling system and oil coolers is used for heating (Maidment and Tozer 2002).

CHP systems are generally more efficient than conventional coal-fired power plants because electricity is produced locally and thus, distribution losses are minimized. In addition, the waste heat from the CHP system can be used for space heating and process heating, thereby increasing overall efficiency. 
In supermarket applications, the waste heat from CHP systems is typically used for space heating and hot water production. This results in under-utilization of the waste heat during warm summer months. To increase the efficiency of CHP systems in supermarket applications, several researchers have suggested integrating an absorption cooling system into the CHP system (Maidment and Tozer 2002) (Sugiartha, et al. 2009) (Arteconi, Brandoni and Polonara 2009). The waste heat from the CHP system drives the absorption cooling system, which in turn, provides cooling for refrigerated display cases, storage areas and the retail space. This concept is known as trigeneration, or combined cooling, heating and power (CCHP).

Typical commercially available trigeneration systems include:

- Gas turbine and electric generator with double-effect, steam driven absorption chiller: In this system, steam is produced via an exhaust gas-to-steam heat recovery boiler. This steam is then used to drive an absorption chiller. This type of system typically has a capacity in excess of $1 \mathrm{MW}_{\mathrm{e}}$.

- Gas engine and electric generator with single-effect, hot water driven absorption chiller: In this system, hot water is produced using the waste heat from the engine exhaust gases and the engine cooling system. This hot water is then used to drive an absorption chiller. This type of system typically has a capacity less than $1 \mathrm{MW}_{\mathrm{e}}$.

The application of trigeneration may result in energy savings when compared to conventional, separately purchased power and on-site thermal energy systems. The cost of the trigeneration system, including first cost, fuel cost and maintenance cost, should be compared to the costs of purchased power and thermal energy. Trigeneration offers the advantage of allowing businesses to remain online during power outages or other disasters.

The installed cost for a combined heating and power (CHP) system, excluding absorption cooling, depends upon the type of engine used to power the system, and can range as follows (EPA 2008):

- Reciprocating engine CHP: $\$ 1,100$ to $\$ 2,200$ per $k W_{e}$

- Gas turbine CHP: $\$ 970$ to $\$ 1,300$ per $\mathrm{kW}_{\mathrm{e}}$

- Microturbine CHP: $\$ 2,400$ to $\$ 3,000$ per $k W_{e}$

Application of trigeneration systems in the food manufacturing and processing industries has been discussed by Bassols et al. (2002), including the use of trigeneration in a margarine factory in the Netherlands, a frozen vegetable factory in Spain, a dairy factory in Spain, and a meat factory in Spain. Nevertheless, trigeneration has had limited application in the food retail market, principally due to the lack of commercially available systems suited for the supermarket industry (Sugiartha, et al. 2009). Recently, however, several researchers, motivated by an effort to reduce energy use and greenhouse gas emissions, have theoretically studied the feasibility of using trigeneration systems in supermarket applications (Maidment and Tozer 2002) (Sugiartha, et al. 2009) (Arteconi, Brandoni and Polonara 2009). In addition, a laboratory study of a micro turbine based trigeneration system with application to supermarkets has been reported by Ge et al. (2009). Furthermore, a field demonstration of a CHP 
system installed in a supermarket in Hauppauge, NY has been performed by CDH Energy Corporation (2004).

\section{Analytical Study by Maidment and Tozer (2002)}

Using a BIN calculation method, Maidment and Tozer (2002) modeled the electrical and thermal performance of several trigeneration systems for a prototypical supermarket. Only gas engine driven systems, rather than gas turbine driven systems, were studied since the power requirements of the prototypical supermarket were much less than $1 \mathrm{MW}_{\mathrm{e}}$. In their analysis, Maidment and Tozer assumed that the absorption chiller would be sized to satisfy only half of the supermarket's cooling load. The other half of the cooling load was assumed to be provided by a conventional vapor compression refrigeration system.

Five trigeneration systems were investigated by Maidment and Tozer, including:

1. High temperature gas engine $\left(255^{\circ} \mathrm{F}\right.$ or $\left.124^{\circ} \mathrm{C}\right)$ with a single effect ammonia/water absorption chiller which cooled propylene glycol. The propylene glycol was then used to cool the medium temperature display cases. Conventional vapor compression refrigeration systems were used for the low temperature display cases.

2. Conventional gas engine $\left(194^{\circ} \mathrm{F}\right.$ or $\left.90^{\circ} \mathrm{C}\right)$ with a double stage ammonia/water absorption chiller which cooled propylene glycol. The propylene glycol was then used to cool the medium temperature display cases. Conventional vapor compression refrigeration systems were used for the low temperature display cases.

3. Conventional gas engine $\left(194^{\circ} \mathrm{F}\right.$ or $\left.90^{\circ} \mathrm{C}\right)$ with a single effect lithium bromide/water absorption chiller which cooled water. The water was then used to remove the waste heat from the vapor compression refrigeration systems of both the medium and low temperature display cases via cascade condensers.

4. Low temperature gas engine $\left(158^{\circ} \mathrm{F}\right.$ or $\left.70^{\circ} \mathrm{C}\right)$ with a low temperature, single effect lithium bromide/water absorption chiller which cooled water. The water was then used to remove the waste heat from the vapor compression refrigeration systems of both the medium and low temperature display cases via cascade condensers.

5. Conventional gas engine $\left(176^{\circ} \mathrm{F}\right.$ or $\left.80^{\circ} \mathrm{C}\right)$ with a silica gel/water adsorption chiller which cooled water. The water was then used to remove the waste heat from the vapor compression refrigeration systems of both the medium and low temperature display cases via cascade condensers.

From the analysis of these five systems, it was found that the conventional gas engine coupled with the single effect lithium bromide/water absorption chiller (Option 3) produced the lowest payback period, which was approximately 7 years. In addition, this particular system produced an estimated primary energy savings of approximately $15 \%$ when compared to a conventional supermarket which received its electricity from a coal-fired power plant. It was noted that this primary energy savings would be beneficial in the short term. However, in the medium to longer term, trigeneration will have to compete against more efficient grid generated electricity, such as that from combined cycle gas turbine (CCGT) generation. Thus, Maidment and Tozer (2002) speculate that in the long term, trigeneration systems 
must be powered by more efficient mini gas turbines or fuel cells, rather than gas engines, in order for trigeneration to be viable for commercial refrigeration applications.

\section{Analytical Study by Sugiartha et al. (2009)}

Sugiartha et al. (2009) presented a methodology to evaluate the energy, economic and environmental performance of a micro-gas turbine based trigeneration system for supermarket applications. A prototype supermarket with a sales area of $30,140 \mathrm{ft}^{2}\left(2800 \mathrm{~m}^{2}\right)$ was proposed, which makes use of absorption chillers supplying chilled brine to the medium temperature display cases. Heat input to the absorption chillers is supplied by the exhaust from micro-gas turbines. The low-temperature display cases are serviced by a conventional direct expansion refrigeration system. For stable system operation, Sugiartha et al. (2009) suggested the use of a thermal storage device placed between the absorption chillers and the medium temperature display cases to balance the variations in refrigeration system load and the refrigerating effect produced by the absorption chiller.

Two operating strategies were investigated: the full electrical load-continuous operation strategy and the heat load-following operation strategy. During full electrical load-continuous operation, the micro gas turbine runs continuously at full electrical power output regardless of the site demand and any heat generated in excess of the heat demand will be rejected to the ambient (Sugiartha, et al. 2009). In the heat load-following operation strategy, the output of the micro gas turbine will be modulated to meet the site heat demand. Thus, the electrical power output of the system will vary. Any deficiency in electrical demand is made up from the grid and any excess electricity can be exported to the grid (Sugiartha, et al. 2009).

The trigeneration system studied by Sugiartha et al. (2009) consisted of two natural gas fired micro turbines capable of producing $80 \mathrm{~kW}_{\mathrm{e}}$ each. At their rated electrical output, the micro gas turbines produce $163 \mathrm{~kW}$ of thermal energy at an exhaust gas temperature of $275^{\circ} \mathrm{F}\left(135^{\circ} \mathrm{C}\right)$. Several $12 \mathrm{~kW}$ ammonia-water absorption chillers were used that can vary depending on the amount of heat available from the micro gas turbines. The electrical rating for the chillers is at an ambient temperature of $95^{\circ} \mathrm{F}$ $\left(35^{\circ} \mathrm{C}\right)$, a brine temperature of $23^{\circ} \mathrm{F}\left(-5^{\circ} \mathrm{C}\right)$ and a brine flow rate of $81 \mathrm{ft}^{3} / \mathrm{h}\left(2.3 \mathrm{~m}^{3} / \mathrm{h}\right)$.

In their analysis, Sugiartha et al. (2009) found that when the fraction of heat generated by the micro gas turbines in full load operation which was diverted to drive the absorption chillers was less than $85 \%$, then the continuous full load operating strategy resulted in better energy, economic and environmental performance. When the fraction of heat generated by the turbines which was diverted to the absorptions chillers was greater than $85 \%$, then the two operating strategies gave similar performance.

Sugiartha et al. (2009) found that the economic viability of the trigeneration system was sensitive to the relative prices of natural gas and grid electricity. When the electricity to gas price ratio is 4.0 , the payback period for the trigeneration system is 5.7 years, assuming the full load operating strategy and a COP of 0.5 for the absorption chillers.

\section{Analytical Study Arteconi et al. (2009)}

Arteconi et al. (2009) present the results of a feasibility study using a trigeneration system to generate electricity and provide heating and air conditioning for a supermarket. This system consists of a natural 
gas fired internal combustion engine or micro turbine coupled with a lithium-bromide/water absorption chiller for air conditioning. Arteconi et al. (2009) also analyzed the feasibility of using a trigeneration system with ammonia/water absorption chillers to service medium temperature refrigerated display cases. In this system, the low temperature refrigerated display cases were serviced with conventional vapor compression refrigeration systems.

The prototypical store, based on an actual supermarket located in central-northern Italy, has a sales area of $107,640 \mathrm{ft}^{2}\left(10,000 \mathrm{~m}^{2}\right)$. The supermarket has a significant demand for heating in the winter months, resulting in an annual thermal energy consumption of $880 \mathrm{MWh}$. The annual electrical energy consumption of the supermarket is $5093 \mathrm{MWh}$, which includes a relatively constant refrigeration system demand. The electricity demand increases slightly in the summer months due to the need for air conditioning and the higher demand for refrigeration.

In their analysis of the prototypical supermarket, Arteconi et al. (2009) found that a trigeneration system which generates electricity with an internal combustion engine and provides air conditioning using a lithium bromide/water absorption system produced a payback period of less than five years.

Furthermore, they found that a trigeneration system using a micro turbine, rather than an internal combustion engine, was not competitive due to the turbine's higher initial cost and lower electrical efficiency as compared to the internal combustion engine.

For the prototypical supermarket, Arteconi et al. (2009) also found that a trigeneration system which generates electricity and provides food refrigeration using ammonia/water chillers produces a payback period of less than five years. Therefore, Arteconi et al. (2009) conclude that the two trigeneration systems studied are viable, both energetically and economically.

\section{CHP Field Studies Sponsored by DOE}

The U.S. Department of Energy has supported more than 350 combined heat and power projects, representing 1.3 gigawatt (GW) of CHP installed or in development, and includes applications such as supermarkets, office buildings, healthcare facilities, educational facilities, and manufacturing facilities, among others (DOE 2011).

A demonstration of CHP in a 57,000 $\mathrm{ft}^{2}\left(5,300 \mathrm{~m}^{2}\right)$ supermarket located in Mt. Kisco, NY has been performed with sponsorship from the U.S. Department of Energy (Rosfjord, et al. 2005). This particular CHP system consists of four $60 \mathrm{~kW}$ microturbines and a waste-heat-driven double effect absorption chiller. The system provides $240 \mathrm{~kW}$ of electricity as well as 110 tons of chilled water or $900 \mathrm{MBTU}$ of hot water. The chilled water provides space cooling as well as refrigerant sub-cooling, and the hot water provides space heating during winter operation. In addition, exhaust heat from the microturbines is used to regenerate the desiccant in a desiccant dehumidification system. It was estimated that grid electricity consumption of the supermarket after installation of the CHP system was $54 \%$ of the store baseline grid electricity consumption. Furthermore, it was estimated that the annual energy savings, including both electricity and gas, would be $\$ 129,000$. 


\section{CHP Field Study by CDH Energy Corporation (2004)}

A demonstration of CHP in a $57,000 \mathrm{ft}^{2}\left(5,300 \mathrm{~m}^{2}\right)$ supermarket located in Hauppauge, NY has been performed by CDH Energy Corporation (2004) with support from the U.S. DOE (DOE 2011). The CHP system consists of a $60 \mathrm{~kW}$ microturbine that generates electricity and a heat exchanger that recovers heat from the microturbine exhaust. The heat exchanger transfers the waste heat to a glycol loop, which in turn provides heat for either the supermarket space or for desiccant regeneration in the dehumidification system, depending upon the season.

During the monitoring period from August 2002 through July 2004, the CHP system delivered, on average, approximately $8 \%$ of the total electrical energy required by the supermarket. The CHP system was able to deliver up to $400 \mathrm{MBtu} / \mathrm{hr}$ for space heating during the winter and approximately $230 \mathrm{MBtu} / \mathrm{hr}$ for desiccant regeneration during the summer.

During space heating with a difference of $50^{\circ} \mathrm{F}\left(28^{\circ} \mathrm{C}\right)$ between the indoor and outdoor temperatures, it was found that heat recovery from the CHP system reduced the gas consumption of the heating system by $33 \%$ (164 therms/day without heat recovery versus 110 therms/day with heat recovery). In addition, with a difference of $20^{\circ} \mathrm{F}\left(11^{\circ} \mathrm{C}\right)$ between the indoor and outdoor temperatures, CHP heat recovery reduced the gas consumption of the heating system by 39\% (from 64 therms/day without heat recovery versus 39 therms/day with heat recovery). It was noted that the control strategy used to initiate heat recovery space heating and gas space heating was not optimized, and thus, roughly only $50 \%$ of the available waste heat from the CHP system was effectively used for space heating of the supermarket.

During dehumidification at a humidity of 120 grains/lb, it was found that heat recovery from the CHP system reduced the gas consumption of the desiccant dehumidification system by approximately $40 \%$ (from 127 therms/day without heat recovery versus 76 therms/day with heat recovery). In addition, at a humidity of 65 grains/lb, $\mathrm{CHP}$ heat recovery reduced the gas consumption of the desiccant dehumidification system by approximately $80 \%$ (from 27 therms/day without heat recovery versus 5 therms/day with heat recovery).

The installed cost of the CHP system, including the microturbine, heat recovery coils, electrical, plumbing, and controls, was $\$ 2,450 / \mathrm{kW}$ (2002 price). It was estimated that if the CHP system were part of the original bid to build the supermarket, the installed cost would have been between $\$ 1,800$ to $\$ 2,000$ per $\mathrm{kW}$. Using the local utility rates, it was estimated that the payback for the CHP system was 30 years.

\section{Fuel Cells}

A fuel cell is a device that combines hydrogen fuel and oxygen to produce electricity, heat and water. The process does not involve combustion, and thus, a fuel cell produces very little pollution. In addition, compared to an internal combustion engine, a fuel cell is capable of extracting more energy from the same amount of fuel. Thus, fuel cells have higher efficiencies compared to internal combustion engines. Finally, fuel cells contain no moving parts, and thus, they represent a quiet and reliable source of power.

A commercially available phosphoric acid based fuel cell is capable of delivering $1.7 \mathrm{MMBtu} / \mathrm{hr}$ of lowgrade heating at $140^{\circ} \mathrm{F}\left(60^{\circ} \mathrm{C}\right)$ and $0.79 \mathrm{MMBtu} / \mathrm{hr}$ of high-grade heating at $250^{\circ} \mathrm{F}\left(121^{\circ} \mathrm{C}\right)$ while 
producing $400 \mathrm{~kW}$ of electric power (UTC Power 2010). This particular fuel cell has been used in several supermarket applications.

Price Chopper's 69,000 $\mathrm{ft}^{2}\left(6,410 \mathrm{~m}^{2}\right)$ Colonie store in New York utilizes a $400 \mathrm{~kW}$ fuel cell as its primary and emergency power source (PR Newswire 2010). The use of the fuel cell in conjunction with an array of environmentally progressive features including advanced systems in cooling and refrigeration, daylight harvesting, as well as waste and recycling initiatives led the U.S. Environmental Protection Agency (EPA) to award the Colonie store with the highest level of GreenChill gold-level certification.

An Albertsons supermarket in California uses a $400 \mathrm{~kW}$ fuel cell to generate approximately $90 \%$ of its electricity requirements (Environmental Leader 2010). The heat from the fuel cell is used to heat the retail space, provide hot water and drive a chiller which supplies refrigeration to display cases. The overall energy efficiency of this installation is reported to be $60 \%$.

A 50,000 $\mathrm{ft}^{2}\left(4,650 \mathrm{~m}^{2}\right)$ Whole Foods Market in San Jose, CA also uses a $400 \mathrm{~kW}$ fuel cell to produce $90 \%$ of the store's electricity requirements and the thermal energy is used for store heating and refrigeration (Renewable Energy Focus 2010). The overall energy efficiency of this installation is reported to be $60 \%$.

A smaller $200 \mathrm{~kW}$ fuel cell is used in a $46,000 \mathrm{ft}^{2}\left(4,270 \mathrm{~m}^{2}\right)$ Whole Foods Market located in Glastonbury, CT (UTC Power 2008). This fuel cell generates $50 \%$ of the electricity and heat required by the store. In addition, this fuel cell provides nearly $100 \%$ of the hot water required by the supermarket.

Currently, the most widely deployed fuel cells cost about $\$ 4,500$ per kilowatt. By contrast, a diesel generator costs $\$ 800$ to $\$ 1,500$ per kilowatt, and a natural gas turbine can be $\$ 400$ per kilowatt or even less (DOE 2010). Thus, due to the high cost of fuel cell technology, many supermarket chains have applied for grants and federal tax incentives to help defray the cost of utilizing fuel cell technology. For example, the New York State Energy Research and Development Authority (NYSERDA) has provided Price Chopper with nearly $\$ 1.2$ million in funding for energy efficiency measures at Price Chopper's Colonie store (NYSERDA 2010). Whole Foods received a $\$ 940,000$ grant from the Connecticut Clean Energy Fund to be used toward the purchase of the fuel cell used at their Glastonbury store (Environmental Leader 2008). The fuel cell project at Whole Foods' Dedham, MA, store received a $\$ 400,000$ grant from the Massachusetts Renewable Energy Trust Large Onsite Renewables Initiative (LORI), which is a program that awards grants for feasibility studies as well as design and construction projects for qualifying renewable energy systems greater than $10 \mathrm{~kW}$ (Fuel Cell Today 2010). Thus, while application of fuel cell technology in supermarket applications can be attractive from an energy and environmental aspect, the current cost of the technology inhibits its wide-spread utilization.

\section{Discussion}

The basic application of refrigeration system waste heat recovery is to provide space heating and water heating for the supermarket. Typically, space heating and water heating are accomplished with gasfired heaters, and thus, waste heat recovery can reduce the gas consumption associated with space heating and water heating. According to the EPA (2008), 74\% of a typical supermarket's gas 
consumption is attributed to space heating while $13 \%$ of its gas use is for water heating. The remaining $13 \%$ of a supermarket's gas consumption is dedicated to cooking requirements.

To determine the energy savings associated with basic heat recovery in a supermarket, a representative supermarket of $40,000 \mathrm{ft}^{2}$ used in an analysis by Walker (2001) was used. The representative supermarket has a floor area of $40,000 \mathrm{ft}^{2}$ and the capacities of the refrigeration system and the HVAC system are given in Table 6 and Table 7, respectively (Walker 2001). As shown in Table 6, a total of $1,667,000 \mathrm{Btu} / \mathrm{hr}$ of waste heat is generated by the supermarket refrigeration system. In addition, the maximum average cooling capacity required for the representative supermarket is 90 tons while the required maximum average heating capacity is 1,042,580 Btu/hr, as shown in Table 7.

Table 6. Specification of Representative Supermarket Refrigeration System (Walker 2001)

\begin{tabular}{ccccc}
\hline \hline Refrigeration Rack & $\begin{array}{c}\text { Evaporator } \\
\text { Load (Btu/hr) }\end{array}$ & COP & $\begin{array}{c}\text { Compressor } \\
\text { Power (kW) }\end{array}$ & $\begin{array}{c}\text { Heat } \\
\text { Rejection } \\
\text { (Btu/hr) }\end{array}$ \\
\hline $\begin{array}{c}\text { Low Temperature } \\
\text { Medium } \\
\text { Temperature }\end{array}$ & 279,370 & 1.3 & 63 & 494,000 \\
Total & 838,960 & 2.5 & 98 & $1,173,000$ \\
\hline \hline
\end{tabular}

Table 7. Cooling Capacity and Heating Load of Representative Supermarket in Various Cities (Walker 2001)

\begin{tabular}{ccc}
\hline \hline Location & Cooling Capacity (TR) & Heating Load (Btu/hr) \\
\hline Worcester, MA & 83.0 & $1,181,055$ \\
Washington, D.C. & 89.4 & $1,000,435$ \\
Memphis, TN & 97.7 & 946,249 \\
Average & 90.0 & $1,042,580$ \\
\hline \hline
\end{tabular}

The heating performance of a typical, commercially available 90-ton rooftop unit (RTU) which could be used for the representative supermarket is shown in Table 8. This RTU provides a maximum of 900,000 $\mathrm{Btu} / \mathrm{hr}$ of heating from a gas input of $1,125,000 \mathrm{Btu} / \mathrm{hr}$, which corresponds to a gas heater efficiency of $80 \%$. 
Table 8. Heating Performance of a Typical 90-Ton Rooftop Unit

\begin{tabular}{cc}
\hline \hline Item & Value \\
\hline Gas Input Capacity (Btu/hr) & $1,125,000$ \\
Maximum Output Capacity (Btu/hr) & 900,000 \\
Minimum Airflow (cfm) & 15,150 \\
Temperature Rise $\left({ }^{\circ} \mathrm{F}\right)$ & $25-55$ \\
\hline \hline
\end{tabular}

Assuming an efficiency of $80 \%$ for the gas-fired furnace, a gas input of 1,303,225 Btu/hr would be required to satisfy the maximum average space heating load of 1,042,580 Btu/hr. According to the EPA (2008), 74\% of a typical supermarket's gas consumption is attributed to space heating while $13 \%$ of its gas use is for water heating. Thus, it is estimated that $183,156 \mathrm{Btu} / \mathrm{hr}$ of heat is required for water heating in the representative supermarket. Assuming an efficiency of $80 \%$ for the gas-fired water heater, a gas input of $228,945 \mathrm{Btu} / \mathrm{hr}$ would be required to satisfy the water heating load of 183,156 $\mathrm{Btu} / \mathrm{hr}$. Overall, the combined space and water heating requirement of the supermarket is 1,225,736 $\mathrm{Btu} / \mathrm{hr}$, which requires a gas input of 1,532,170 Btu/hr.

Assuming that hot water demand is constant throughout the year, and that the duty cycle of the gasfired water heater is 0.4 , the total annual gas input required to produce hot water would be $802 \times 10^{6} \mathrm{Btu}$. Assuming 1 cubic foot of natural gas is equivalent to $1,027 \mathrm{Btu}$, and with an average price for natural gas of $\$ 14.62$ per thousand cubic feet (EIA 2011), it is estimated that the cost of producing hot water via a gas-fired water heater would be $\$ 11,417$ per year. Furthermore, assuming that space heating is required during six months out of the year and that the duty cycle of the space heating system is 0.4 , the cost associated with gas-fired heating of the supermarket would be $\$ 32,504$ per year. Thus, without utilizing waste heat, the combined annual cost of water and space heating is estimated to be $\$ 43,921$.

Assuming that $40 \%$ of the waste heat from the refrigeration system can be recovered for useful purposes, it can be seen that as much as $666,800 \mathrm{Btu} / \mathrm{hr}$ of useful heat is available from the refrigeration system for space heating and water heating. Since the total space and water heating requirement of the supermarket is $1,225,736 \mathrm{Btu} / \mathrm{hr}$, waste heat reclaim can provide, at a minimum, $54 \%$ of the required heat, leaving 558,936 Btu/hr which must be supplied via the gas-fired furnace and gas-fired water heater. Assuming, an efficiency of $80 \%$ for the gas-fired furnace and water heater, a total gas input of $698,670 \mathrm{Btu} / \mathrm{hr}$ is required to satisfy the $558,936 \mathrm{Btu} / \mathrm{hr}$ space and water heating requirement that is not met by waste heat recovery.

Thus, in the worst case scenario when space heating and water heating are required simultaneously, such as during the winter, simple heat reclaim can save $54 \%$ in gas consumption. On the other hand, in the summer when only water heating is required, simple heat reclaim can provide $100 \%$ of the energy 
required for water heating. On an annual basis, the gas energy cost when utilizing simple heat recovery is estimated to be $\$ 21,583$. This represents an annual gas energy cost savings of $51 \%$ as compared to not utilizing heat recovery.

It should be noted that the actual amount of waste heat available from a supermarket refrigeration system depends upon climate, season and operating strategy. Thus, energy savings associated with waste heat recovery are dependent upon climate zone, seasonal weather variations and refrigeration system operation (i.e., floating head pressure vs. fixed head pressure).

In addition to the analysis of simple heat recovery discussed above, Table 9 summarizes the advanced heat recovery technologies identified in this study. The estimated total supermarket electrical energy savings is reported along with the gas energy savings associated with space heating and water heating (assuming that all space heating and water heating would be otherwise provided by gas-fired heaters). Note that the gas energy savings shown in Table 9 represents only that portion associated with space heating or water heating. CHP/CCHP and fuel cell technologies typically require a natural gas source for operation which would be in addition to any space heating and water heating requirements. In addition, cost and payback are reported for the heat recovery technologies.

The use of heat pumps to increase the availability of the refrigeration system waste heat has the potential to offset nearly all of the heating requirements of a supermarket. This strategy would be especially beneficial to supermarkets located in colder climates where heating is required for a significant portion of the year. Furthermore, the refrigeration system may employ a floating head pressure strategy without negatively affecting the ability of the heat pumps to recover useful waste heat from the refrigeration system.

$\mathrm{CHP} / \mathrm{CCHP}$ and fuel cell technologies have the capability of providing nearly all of the electrical and thermal energy required by a supermarket. While the application of these technologies in supermarkets can be attractive from an energy and environmental aspect, the current cost of these technologies inhibits their wide-spread utilization.

Another factor which may influence the waste heat recovery strategy selected for a supermarket is compliance with state and federal energy codes. The State of California is currently considering the inclusion of mandatory waste heat recovery for supermarkets in the 2013 version of their Title 24 building energy efficiency standard (PG\&E 2011) (CEC 2008). Depending upon climate zone, it is proposed that supermarkets will be required to utilize at least $25 \%$ of the refrigeration system waste heat for space heating. However, this should be done without increasing the hydrofluorocarbon (HFC) refrigerant charge of the refrigeration system by more than $20 \%$ of the total charge without heat recovery, or 0.50 pounds per $1,000 \mathrm{Btu} / \mathrm{hr}$ of heating capacity $(0.77 \mathrm{~kg} / \mathrm{kW})$, whichever is less. While this proposed code is only currently applicable to California, it is conceivable that this code may eventually be included in federal building energy efficiency regulations. 
Table 9. Summary of Advanced Heat Recovery Technologies.

\begin{tabular}{|c|c|c|c|c|c|c|}
\hline $\begin{array}{c}\text { Heat Recovery } \\
\text { Technology }\end{array}$ & $\begin{array}{l}\text { Total Electrical } \\
\text { Energy Savings } \\
(\%)\end{array}$ & $\begin{array}{c}\text { Space } \\
\text { Heating Gas } \\
\text { Energy } \\
\text { Savings (\%) }\end{array}$ & $\begin{array}{c}\text { Water } \\
\text { Heating } \\
\text { Gas } \\
\text { Energy } \\
\text { Savings } \\
(\%)\end{array}$ & Cost & Payback & Notes \\
\hline $\begin{array}{l}\text { Heat pumps, } \\
\text { refrigerant } \\
\text { coupled }\end{array}$ & $6 \%$ & $>90 \%$ & & $\begin{array}{c}8 \% \text { more than } \\
\text { conventional } \\
\text { HVAC\&R }\end{array}$ & & \\
\hline $\begin{array}{l}\text { Heat pumps, } \\
\text { liquid loop } \\
\text { coupled }\end{array}$ & $8 \%$ to $15 \%$ & $>90 \%$ & & $\begin{array}{c}30 \% \text { more than } \\
\text { conventional } \\
\text { HVAC\&R }\end{array}$ & 4 to 8 years & $\begin{array}{c}\text { Less } \\
\text { refrigerant } \\
\text { charge as } \\
\text { compared to } \\
\text { refrigerant } \\
\text { coupled heat } \\
\text { pumps }\end{array}$ \\
\hline $\begin{array}{l}\mathrm{CHP} / \mathrm{CCHP}, \\
\text { large system }\end{array}$ & $>90 \%$ & & & $\begin{array}{c}\$ 1,000 \text { to } \\
\$ 3,000 \text { per } \mathrm{kW}\end{array}$ & 5 to 7 years & $\begin{array}{l}\text { Expensive. } \\
\text { Requires } \\
\text { fossil fuel for } \\
\text { engine. }\end{array}$ \\
\hline $\begin{array}{c}\mathrm{CHP} / \mathrm{CCHP}, \\
\text { small system } \\
(60 \mathrm{~kW})\end{array}$ & $10 \%$ & $33 \%-39 \%$ & & $\begin{array}{c}\$ 1,000 \text { to } \\
\$ 3,000 \text { per } \mathrm{kW}\end{array}$ & & $\begin{array}{l}\text { Expensive. } \\
\text { Requires } \\
\text { fossil fuel for } \\
\text { engine. }\end{array}$ \\
\hline $\begin{array}{c}\text { Fuel Cells, large } \\
\text { system (400 } \\
\text { kW) }\end{array}$ & $>90 \%$ & $>90 \%$ & $>90 \%$ & $\$ 4,500$ per $\mathrm{kW}$ & & $\begin{array}{c}\text { Very } \\
\text { expensive. } \\
\text { Requires } \\
\text { natural gas. }\end{array}$ \\
\hline
\end{tabular}

The proposed California regulations allude to an environmental as well as an energy impact associated with waste heat recovery. The basic method of waste heat recovery, which makes use of heating coils placed within HVAC systems or water heating systems, requires piping and refrigerant beyond that which is required for a refrigeration system without heat reclaim. While an energy benefit may be realized from the use of basic waste heat reclaim, the increase in associated piping and refrigerant charge can lead to adverse environmental impacts. Additional piping increases the potential risk for refrigerant leaks while an increase in refrigerant charge increases the quantity of refrigerant which can escape into the environment. Thus, when evaluating waste heat recovery options, it would be prudent to consider the environmental impacts of the waste heat recovery system.

When considering the use of heat pumps to enhance heat recovery, refrigerant coupled heat pumps will require more refrigerant piping and refrigerant charge than the liquid loop coupled heat pumps. In the refrigerant coupled heat pump strategy, the refrigeration system discharge piping from the compressor is routed to a heat exchanger which serves as the evaporator of the heat pump. Thus, potentially long 
refrigerant lines, and an associated increase in refrigerant charge, are required to transfer the energy from the discharge gas to the heat pump. On the other hand, in the liquid loop coupled heat pump strategy, the heat from the refrigeration system discharge is transferred to a secondary fluid via a heat

exchanger. This fluid is then pumped to a second heat exchanger which serves as the evaporator of the heat pump. Thus, the long refrigerant lines between the refrigeration system discharge and the heat pump are replaced with long secondary fluid lines. Therefore, the potential for leakage of high global warming potential fluids is reduced when using the liquid loop coupled heat pump strategy.

\section{Conclusions}

The objective of this project was to determine the potential energy savings associated with improved utilization of waste heat from supermarket refrigeration systems. Existing and advanced strategies for waste heat recovery in supermarkets were analyzed, including options from advanced sources such as combined heat and power (CHP), micro-turbines and fuel cells.

It was estimated that the implementation of simple heat recovery, where refrigerant-to-air and/or refrigerant-to-water heat exchangers transfer heat from the compressor discharge gas to either the retail space or process water, can produce annual gas energy savings of approximately $50 \%$ for a typical supermarket, assuming that space heating and water heating are typically supplied by gas-fired heaters. It has been noted that in order to achieve these savings, the basic heat recovery system must be effectively designed and integrated into the HVAC system using sophisticated control systems (Arias and Lundqvist 2006).

The use of heat pumps for waste heat recovery in supermarket applications has the potential to provide up to $100 \%$ of the required space heating for a typical supermarket. If it is assumed that gas-fired heaters provide space heating for a typical supermarket, then the use of heat pump heat recovery could save up to $100 \%$ in gas energy use. It has even been reported that a slight electrical energy savings can be realized by using heat pump waste heat recovery even though the heat pumps require electrical energy to operate (Baxter 2003). Furthermore, the refrigeration system may employ a floating head pressure strategy without negatively affecting the ability of the heat pumps to recover useful waste heat from the refrigeration system. The initial cost associated with heat pump heat recovery has been reported to be anywhere from $8 \%$ to $30 \%$ more than conventional HVAC\&R systems, with a payback of four to eight years.

Depending upon unit capacity, combined cooling, heating and power (CCHP) and fuel cell technology have the potential to supply up to $100 \%$ of the electrical and thermal energy needs of a typical supermarket. CCHP and fuel cells can provide supermarkets with high temperature waste heat for space heating and water heating applications. In addition, the waste heat can even be used to drive absorption refrigeration systems. While CCHP and fuel cells can provide a supermarket with a source of electrical energy during power outages or other disasters, they do require a fossil fuel source such as natural gas to operate. Due to the high initial cost of these systems, the implementation of CCHP and fuel cells has been limited. A CCHP or fuel cell system can cost anywhere from $\$ 1,000$ to $\$ 4,500$ per $\mathrm{kW}$. The payback for such a system has been estimated to be between five to seven years, and even up to 30 
years for an actual CHP system installed in a supermarket (CDH Energy Corporation 2004). Typically, grants and tax incentives have been used to help defray the cost of utilizing these advanced heat recovery sources.

Thus, a well-designed simple heat recovery system or a heat pump based heat recovery system appears to be the most economical and energy efficient choices for a majority of supermarket applications. While CCHP or fuel cell systems are attractive from the standpoint of energy efficiency and energy independence, they are currently cost-prohibitive in most supermarket applications. 


\section{Bibliography}

Arias, Jaime, and Per Lundqvist. "Heat recovery and floating condensing in supermarkets." Energy and Buildings 38, no. 2 (2006): 73-81.

Arteconi, A., C. Brandoni, and F. Polonara. "Distributed generation and trigeneration: Energy saving opportunities in Italian supermarket sector." Applied Thermal Engineering 29, no. 8-9 (2009): 1735-1743.

Bassols, J., B. Kuckelkorn, J. Langreck, R. Schneider, and H. Veelken. "Trigeneration in the food industry." Applied Thermal Engineering 22, no. 6 (2002): 595-602.

Baxter, V.D. IEA Annex 26: Advanced Supermarket Refrigeration/Heat Recovery Systems - Final Report Volume 1 - Executive Summary. Boras, Sweden: IEA Heat Pump Centre, 2003.

Brandemuehl, M.J., and M.K. Khattar. "Demonstration and Testing of an All-Electric Desiccant Dehumidifying System at a New Jersey Supermarket." ASHRAE Transactions 103, no. 1 (1997): 848-859.

CDH Energy Corporation. Final Report - Demonstrating a Combined Heat and Power (CHP) System: An Integrated Microturbine/Desiccant System for Supermarket Applications. Cazenovia, NY: CDH Energy Corporation, 2004.

CEC. California Code of Regulations, Title 24, Part 1: 2008 Building Energy Efficiency Standards for Residential and Nonresidential Buildings. CEC-400-2008-001-CMF, Sacramento, CA: California Energy Commission, 2008.

DOE. DOE's Fuel Cell R\&D Program. 2010. www.fossil.energy.gov/program/powersystems/fuelcells (accessed December 28, 2010).

—. ITP Industrial Distrubted Energy: Combined Heat and Power Projects. 2011. http://www1.eere.energy.gov/industry/distributedenergy/chp_projects.html (accessed October 4, 2011).

EIA. U.S. Energy Information Administration - Independent Statistics and Analysis. 2011. www.eia.doe.gov (accessed February 25, 2011).

Environmental Leader. Supermarket Installs 400-kW Fuel Cell. August 31, 2010. http://www.environmentalleader.com (accessed December 17, 2010).

-. Whole Foods Powers Store with Fuel Cell. March 11, 2008. http://www.environmentalleader.com (accessed December 28, 2010).

EPA. Catalog of CHP Technologies. Washington, D.C.: U.S. Environmental Protection Agency, 2008.

EPA. ENERGY STAR ${ }^{\circledR}$ Building Upgrade Manual. Washington, D.C.: U.S. Environmental Protection Agency, 2008. 
Fuel Cell Today. Second UTC Fuel Cell for Whole Foods Market. 2010. http://www.fuelcelltoday.com (accessed December 28, 2010).

Ge, Y.T., S.A. Tassou, I. Chaer, and N. Suguartha. "Performance evaluation of a tri-generation system with simulation and experiment." Applied Energy 86, no. 11 (2009): 2317-2326.

Khattar, M. Electric Dehumidification and Humidity Control: Principles and Applications. EPRI TR1007394, Palo Alto, CA: Electric Power Research Institute, 2004.

Maidment, G.G., and R.M. Tozer. "Combined Cooling Heat and Power in Supermarkets." Applied Thermal Engineering 22, no. 6 (2002): 653-665.

Minea, Vasile. "Improved Supermarket Refrigeration and Heat Recovery System." ASHRAE Transactions 112, no. 2 (2006): 592-596.

Minea, Vasile. "Supermarket Refrigeration System with Completely Secondary Loops." ASHRAE Journal 49, no. 9 (2007): 40-56.

Minea, Vasile. "Using heat pumps for energy recovery in supermarket refrigeration systems." IEA Heat Pump Centre Newsletter 28, no. 4 (2010): 24-30.

NYSERDA. NYSERDA Supports Energy Efficiency at Golub Corporation. New York, NY: New York State Energy Research and Development Authority, 2010.

PG\&E. Supermarket Refrigeration Codes and Standards Enhancement Initiative (CASE). San Francisco, CA: Pacific Gas and Electric Company, 2011.

PR Newswire. Price Chopper Supermarket First to Power Store with 400 Kilowatt Fuel Cell Unit. January 21, 2010. http://www.prnewswire.com (accessed December 17, 2010).

Renewable Energy Focus. UTC Power fuel cell for San Jose supermarket. February 1, 2010. http://www.renewableenergyfocus.com (accessed December 17, 2010).

Rosfjord, T., T. Wagner, B. Knight, R. Fiskum, and R. DeVault. "Research, Development, and Demonstration of Packaged Cooling, Heating, and Power Systems for Buildings." U.S. Department of Energy Distributed Energy Peer Review. Arlington, VA: U.S. Department of Energy, 2005.

Royal, R. "Heat Recovery in Retail Refrigeration." ASHRAE Journal 52, no. 2 (2010): 14-22.

Sugiartha, N., S.A. Tassou, I. Chaer, and D. Marriott. "Trigeneration in food retail: An energetic, economic and environmental evaluation for a supermarket application." Applied Thermal Engineering 29, no. 13 (2009): 2624-2632.

UTC Power. Model 400 PureCell System: Product Data and Applications Guide. South Windsor, CT: United Technologies Company, 2010. 
UTC Power. Whole Foods Market: New Supermarket is First Ever to Employ On-Site Fuel Cell Technology. South Windsor, CT: United Technologies Company, 2008.

Walker, D.H. Development and Demonstration of an Advanced Supermarket Refrigeration/HVAC System. ORL-970163, Oak Ridge, TN: Oak Ridge National Laboratory, 2001.

Walker, D.H., T.L. Tsaros, and G.I. Deming. Guide for the Selection of Supermarket Refrigeration Systems. CU-6740, Palo Alto, CA: Electric Power Research Institute, 1990.

Westphalen, D., R.A. Zogg, A.F. Varone, and M.A. Foran. Energy savings potential for commercial refrigeration equipment. Washington, D.C.: Building Equipment Division, Office of Building Technologies, U.S. Department of Energy, 1996. 